\title{
Response
}

\section{How to do things with historical texts}

\author{
Richard Biernacki \\ Department of Sociology, University of California, San Diego, La Jolla, CA \\ 92093-0533, USA.
}

This article relates to 10.1057/ajcs.2014.13

American Journal of Cultural Sociology (2015) 3, 311-352.

doi:10.1057/ajcs.2015.8

\section{Introduction}

It is a sterling event for Lee and Martin (2015, hereafter 'LM') to have delivered in this journal a discerning critique of my book Reinventing Evidence in Social Inquiry and a radical departure from humanistic reading. Let me try to review their primary reasons for shifting the evaluation of texts away from coding toward the computerized numerating of words. Despite the technicist ring to their proposal, Lee and Martin acknowledge that the extraction of unit facts from a text comprises only a starting point for interpretation (LM, pp. 15, 24).

Drawing on analogies better than mine, Lee and Martin cement my book's thesis that descriptive coding of texts misleads us because it 'imposes interpretations as opposed to drawing them out in such a way that they can be made subject to critique' (LM, p. 1). They diagnose how coders rely on prior assumptions about the gist of a text as a whole as a requisite for categorizing the sense of its parts or its meaningful properties (LM, p. 4). Given illimitable contexts by which to construe a text's design, guessing its import as a whole is never carried out by standardizable, transparent procedure, so neither is the coding of textual dimensions or portions. Coding is subject to the hermeneutic circle but keeps this dependence under wraps. The method thereby subverts its scientific goal, that of 'substituting intersubjectively valid and “checkable” claims for personalistic ones' (LM, p. 4).

Second, Lee and Martin pivot from this critique to practical criteria for scientific reliability. Above all, creating data about meanings must be carried out independently of initial apperception of texts and it must not aggregate 
text elements under labels of a researcher's choosing (LM, pp. 14, 23-24). In addition, the method should condense contents to facilitate shared discussion of final interpretations, should make the falsifying of weak hypotheses more obvious and should privilege bluntness over statistical manipulation capable of filtering evidence behind the scenes (LM, pp. 14, 22, 24, 32). From their standpoint, counting words and their co-occurrences within paragraphs satisfy these criteria: words can be registered robotically as discrete units, their relations are traceable by physical proximity and counting word patterns aggregates semantic relations already lodged in the text or at least does not impose casespecific presumption (LM, pp. 15, 30-31). Their provocative technique might not remain the only mode of computing that they someday advocate, but as Lee and Martin acknowledge, ' $[\mathrm{I}] \mathrm{t}$ is our claim that what sociology can offer the study of culture is this formal approach' (LM, p. 21).

Third, Lee and Martin illuminate how their method deals with the treacherous act of interpreting atomized unit facts in turn. They aspire to delay (as long as feasible) this moment of meaning determination until the sociological community can share a reduced, manageable diagram of a text's essentials (LM, pp. 10, 24). If I comprehend, they trust that 'a radical dumbing down' via counting lends itself to consensus-building conclusions about what can be asserted reliably about a text (LM, pp. 16, 21). I gather they chose to apply their method to texts of the Frankfurt School because these are exemplars of highbrow classics whose complexity challenges systematic comparison and inference (LM, p. 17). Reductive formalizing aims to found interpretation upon unit facts and to execute it with transparency, facilitating (if not guaranteeing) intersubjective convergence upon key meanings (LM, pp. 9, 20).

If this synopsis approximates the audacious positive program, I should balance it with Lee and Martin's conscientious disclaimers. Lee and Martin never undertake to prove that sociologists 'should' use counting methods, only that it is an option for treating texts as data without the fallacies of coding (LM, p. 20). They do not claim that counting can replace humanistic criteria or is indubitably superior to it. They acknowledge 'a cost to the condensation of reality' but they pull out the props to dramatize it as a sacrifice we make ineluctably once we commit to the stern ideals of science rather than to the enchantment of the literary and esthetic (LM, pp. 20, 22, 25). The burden must be shouldered despite misestimates and despite unverified assumptions about the comparability of counts, drawbacks that Lee and Martin admirably accent with frankness (LM, pp. 17-18, 30).

In response let me recall my broader critique of coding for attempting to sort text portions by standardized labels and for supposing textual meaning is estimable by aggregating unit-facts. These problems appear to deepen with Lee and Martin's atomizing. Then I will revisit their trial runs upon Frankfurt School works to assess whether cartography offers epistemological pay-offs. Does it generate foundational facts before global suppositions about a text's business in 
its world? Do graphs of word proximity lucidly trace conceptual relations? Does formalizing adjudicate between hypotheses more decisively than humanistic reading? Does numerating inspire productive questions about texts and approaches to puzzle solving? Do its procedures fulfill minimal requirements for science as conventionally understood? Does counting offer a useful supplement to humanistic reading? After explicating why the answer to each is probably 'no', I will adumbrate humanist criteria for evaluating hypotheses and explain why formalizing textual strands of evidence undermines rigorous testing of interpretation. My positive conclusion here, as in my book, is that humanistic reading on its own stands closer to science as conventionally understood than does counting or than does the combination of counting with humanistic reading. It better engages standards for validity, transparency, producing competing hypotheses, generalizing and hypothesis-testing by recalcitrant detail.

Quasi-automated formalizing of cultural artifacts already fills the sea of the digital humanities, and sociologists may not be poised to outrace NSA scientists or quantitative linguists. Technique does not justify a discipline's approach. Sociologists' use of textual artifacts is distinctively valuable only when it explains meaningfully orchestrated human action, whereas addressing that task of synthesis looms as a weakness of techniques for reductive formalizing.

\section{How My Critique of Coding was Positioned}

In Reinventing Evidence, I disassembled the maneuvers of three well-known works whose crux was coding, the better to clarify how opaque construals arise out of the attempt to merge two incompatible universes: the sampling and variable analysis of the 'hard' sciences versus the interpretation of contextual meaning from the humanities (Biernacki, 2012b, pp. 8-9; 76-77, 121). In a review of method that struck me as an affidavit of principles, Griswold in 1987 advocated such a marriage of contrarieties when she affirmed that 'the sociology of culture can both subject its cultural interpretations to the definitional precision and validation criteria typical of the social sciences and be as sensitive to the multivocal complexity of cultural data as art history or theology' (Griswold, 1987a, p. 4). By the term coding I indicated that a researcher took reasonable care to subsume texts or text elements under categories so that the classifying was 'traceable and retrospectively explicable, if not mechanically justifiable or reproducible' (Biernacki, 2012b, p. 6). Unlike Lee and Martin, I framed adequacy as the threshold for understanding how a coder had proceeded in some retrospectively plausible and consistent manner, not ideally as the push toward one result as correct. It is difficult to tread this line, but I tried to maintain it by calling my readings 'tentative' and 'suspicious', by excerpting and footnoting so readers could pose doubts any which way, and by 
exposing insecurities in my early published coding (Biernacki, 2012b, pp. 8, 127, 131, 158 n. 17, 191 n. 111). ${ }^{1}$

The uncertainties in outputted 'data' that my book claims to document do not comprise decisive anomalies, since I emphasized instead that coding did not have to be independently replicable (Biernacki, 2012b, p. 6). What remains shocking is how unfathomable and internally inconsistent coding's demotion of semantic complexity can appear when one compares the sociologists' canonical conclusions to the veritable population of texts. I tried to suggest with taxing examples in Reinventing Evidence that texts or their segments can scarcely be sorted by criterial categories of interest to sociologists because meaning and intention stand at a remove from bare expression (Biernacki, 2012b, pp. 36-37, 130-131). The multiple levels that comprise a text - reportage, para-commentary, qualification, keying, narrative and logical sequencing, illocutionary footing - all help authors stake out sophisticated, efficacious positions but also confound nominal coding (Goffman, 1974). For example, in 'The Fabrication of Meaning', Griswold sorts original reviews of the novels of George Lamming by whether they delivered positive versus negative/mixed reactions (Griswold, 1987b). As we know, the purpose of a book review is to build a critical point of view, not to choose among regimented verdicts. So the firm 'data' that seem to result from the coding necessarily cram nuanced reflections into univocal boxes in retrospectively inexplicable ways (Biernacki, 2012b, pp. 98-108). Is it approvingly 'positive' for a reviewer to recommend purchase of a novel to librarians by saying 'Despite its weaknesses, this book deserves reading' (Library Journal, 1972, p. 2645)? Another reviewer of Lamming wrote 'The fluency of his poetic style calls for his admiration: certain passages are so striking by their perception and expression that it seems churlish to suggest that the poetry is overdone'. The reviewer has not affirmed that the language is overworked, only that it would be unfair to complain - or is the conditional statement itself intended to complain (Times British Colonies Review, 1953)? Another critic said that Lamming 'is easily among the best of young writers in English' yet went on about his reliance on 'clotted, incantatory and repetitious prose'. What to make of 'distinct achievement' while 'not always convincing'? Or 'cumulative effect' is 'impressive' but 'appears to lose the direction of his novel'? 'Virtuoso's ear' yet 'fails to get the most out of its characters'? At www.biernackireviews.com I invite readers to experience these complex wordings and others first hand.

Of course we might imagine researchers competently coding for an item so banal as, say, 'reference to a foreign land', at least if they disqualify words featured only in metaphor, metonymy and much else that comprises language as we know it. Reliable banality is what Paul DiMaggio (2013) may have had in mind when he rejected coding because 'the more analytically interesting are the

${ }^{1}$ I also tried to clarify logically that I did not land on a stable solution for the sampling of film reviews (Biernacki, 2012b, pp. 134-136; cf LM 5 n. 2). 
research questions, the harder it is to reach acceptable levels of inter-coder reliability' (DiMaggio et al, 2013, p. 577). The pragmatic footing of expression has proven essential for connecting expression to action, whereas that inflection and social embedding is what coding cannot usefully obtain (Taylor, 1979, p. 68; Hanks, 1996; Biernacki, 2014b, pp. 179, 184).

Meanings are non-itemizable and escape quantitative reasoning because what goes unmentioned in discussion can register as more salient for action than what attracts remark. For example, to examine the narrative weight of anti-Semitism in an autobiography of an exemplary Nazi, Peter Bearman and Katherine Stovel coded the contents of individual clauses regarding Jews (Bearman and Stovel, 2000, p. 88). Reading the Nazi's story as one whole suggests to me he selected life incidents by how they iterated a search for a 'folk community' or Volksgemeinschaft (Biernacki, 2012b, pp. 44-46). This popular term did not refer to Jews overtly, but in practice its connotation of a community of kin left little role for Jews in the future. When this Nazi stops mentioning Jews after Hitler assumed power, the silence may be more ominous than had he continued to belabor encounters with them (Biernacki, 2012b, p. 42). Certainly it looks as if the grand theme of Germans bonding in an exclusive community filtered the incidents the Nazi chose to describe, rendering Bearman and Stovel's coding of anti-Semitism in this or that atomic clause only a tally of surface features in artificially isolated units (Biernacki, 2012b, pp. 49-51).

In addition, our basic understanding of texts in general includes the notion that their parts are articulated within an encompassing argument or narrative arc. For instance, in John Evans' Playing God? (Evans, 2002) it may be unclear whether a sophisticated bioethicist who lists commonly accepted guidelines for bioethics at the outset of an article is endorsing them or is disqualifying them as he builds toward transcending those guidelines in conclusion (cf Ankersmit, 2001, pp. 46-47; Biernacki, 2009, p. 256). Analogously, as I endeavored to show, a Nazi autobiography may frequently register family separations, but if those mentions lead to a triumphant family reunion at Christmas, their meaning is unlike countable bits, even were one to improve upon Bearman and Stovel's counts by balancing separations against instances of rejoining. Detached incidents bear no unit-meanings to tally when they communicate as foreshadowing in an entire arc that is sealed with a climax (Biernacki, 2012b, pp. 46-48).

My critique of coding is therefore broader than that of Lee and Martin first because I think that in attempts to catch the gist of a text, it is nonsense to discuss issues of reliability with respect to the meaning of discrete parts - 'mentions', 'clauses' or isolated affirmations. The meanings the parts bear are fused with higher-order segments or the whole, a principle that Lee and Martin ignore when they decontextualize words for the sake of treating each usage as equal in weight and semantic bearing. For me, casting the problem as that of removing a 'halo' effect is fanciful (LM, p. 6).

Second, my critique of coding is broader because I emphasize that if a coding scheme could reliably digest bits of evidence, the architecture of the coding 
scheme itself induces its own syntax and network of contrasts (Biernacki, 2012a, 2012b, pp. 15-16, 140). If we code Nazis' sentences by themes so basic as 'order' versus 'chaos', as Bearman and Stovel do, are ideological Nazi's engaging in cognitive over-simplification or just us, the sociologists (Biernacki, 2012b, pp. 53-54)? 'The "rationalization" of the evidence of a public discussion is directly induced by the tools of measurement', Berrebi-Hoffman summed up. 'In other words, by the very act of coding one decontextualizes the givens and in effect rationalizes them, enabling one to attribute one's own results to the discussants themselves' (Berrebi-Hoffman, 2013, p. 188). Therefore when Lee and Martin evade coding by having their computer log words, this does not solve the problem that their architecture for transforming and re-projecting the text imposes a semantic system of its own and steers the outputted message (Biernacki, 2012a, 2012b, p. 137). Even mechanical cartograms in Nelson Goodman's analysis of representation 'are as productive as reproductive' (Goodman, 1978, p. 101). When Lee and Martin enumerate co-occurences of words within paragraphs as equatable constituents, they impose a global semiotic system that instigates its own forms of interconnection and 'semanticity', just as linguists predict (Busa, 1980, p. 88; Lucy, 1997). Methods for encrypting information become plausible only in conjunction with the prior hermeneutic theory needed to support them (Duhem, 1962).

One cannot help but admire Lee and Martin's epistemological purism when they segregate machine processing of text (to forge cartograms of word tallies) from interpretive decoding (of this quantitative yield). As they underscore by recalling Kant's Critique of Practical Reason, judgments of meaning do not rest upon and are not verifiable by rule-like protocol. To propose my own example, readers cannot identify words as literal versus figural in a text with 100 per cent agreement, in part because it is difficult to decide whether authors put both senses into play at the same time (Empson, 1951, pp. 67-68; de Man, 1979, p. 131). Nor does anyone expect machines to identify the difference (Geeraerts, 2010, p. 262). Yet imagine we had trained a sect to converge on one take of a word or word-pair, as in a perfect team of coders. People would achieve agreement due only to training for that purpose, making the validity of the results depend circularly on fabricated consensus (Schulz, 1958, p. 512). Without a naturally given bulls-eye, we do not know if hitting an identical spot lends us a viable reading. Or as Franzosi (2004) inferred, 'nonrandom error (validity) is much more likely to distort historical data than random error (reliability)' (pp. 182-183).

If I comprehend, Lee and Martin suggest that the attempt to draft algorithms by which machines can mimic processes of human judgment confronts an analogous problem of circular authority (LM, pp. 22-23). To extrapolate, imagine that the machine for an ambiguous or multi-vocal passage chose readings that diverged from some human judgment, but did so in a manner that made its output plausible after the fact, thanks to the machine's algorithmic 'insight'. Then no supervening adjudication could be invoked, assuming a rule requires its faithfulness to the text to be justified, rather than announced by 
procedure itself (Kjellmer, 1993; LM, p. 23). As Lee and Martin remind us, the distance between computerized and human judging of meaning is insurmountable in any event. We identify meaningful parts by family resemblance to vivid prototypes, whereas computers classify in a different key via criterial ordinances (LM, pp. 5, 21, 22; Biernacki, 2012b, pp. 146-147). In all, Lee and Martin demonstrate better than I did that meaning is not a property that can be extracted and authenticated by algorithms or 'explicit rules' (LM, p. 4). In their negative critiques, they include the issue of decisive yet mercurial contexts in assessing a procedure's validity. When they develop a positive alternative, however, they narrow the challenge to that of initially excluding context in data production. Counting promotes procedural regularity but neglects affirmable validity, an option that Franzosi dissected for sociologists as a poor wager (Franzosi, 2004, pp. 182-183, 225).

\section{Lee and Martin's Ideology of Lexical Units}

To escape from the hermeneutic circle by which a researcher at one point projects meaning from a master hypothesis onto a text's subparts to help decide what they stand for, Lee and Martin pretend that each subpart ordinarily bears a tidy basic meaning in isolation. Allegedly a census of words anatomizes a text because each word or word pair usefully approximates a concept or conceptual relation (LM, p. 29). The very headings of Table A1 convert brute scanned marks into 'semantic relations' (LM, p. 31), thanks to our native folk ideology by which a word unit generally matches up one-to-one with a signified (Silverstein, 1979). From my standpoint, even granting generous measurement error, only a primitive brand of positivism would authorize collapsing atomic words or pairs into atomic concepts or relations. To choose works of the Frankfurt School for this pulverizing is to hatch exquisite technicist revenge.

Not once do Lee and Martin quote from the material counted, so we never learn which English translation of Dialectic of Enlightenment they selected nor which of several German variants are in play (Noerr, 2002, pp. 238-247). To appreciate the exhausting semantic diffraction within a version, browse Horkheimer and Adorno's original 1944 mimeo of this work for occurrences of the locution that Lee and Martin tot up as pivotal, 'reason' (Vernunft):

1. 'Heute bestätigen sie bloss noch den Sieg der technologischen Vernunft über die Wahrheit' (Horkheimer and Adorno, 1944 [hereafter HA], p. 169). Stunt films validate the triumph of technological reason over truth.

2. Christians who talked themselves into believing with a bad conscience 'had to confirm their eternal bliss with the worldly ruin of those who did not make the murky sacrifice of reason' (HA, p. 220). Here reason may stand for secular questioning of faith. 
3. 'The hat bells of the fool do not jingle, rather the key chain of capitalist reason [Vernunft], which even in the image encompasses joy in the goal of getting ahead' (HA, p. 175).

4. 'But the hiding places of an unreflective artistry, which represents the human against the social mechanism, are relentlessly ferreted out by organizational reason (planende Vernunft] ...' (HA, pp. 175-176). Here reason appears similar to organizational 'logic'.

5. 'Vernunft als transzendentale überindividuelle Ich enthält die Idee eines freien Zusammenlebens der Menschen' (HA, p. 100). 'Zugleich jedoch bildet Vernunft die Instanz des kalkulierenden Denkens, das die Welt für die Zwecke der Selbsterhaltung zurichtet und keine anderen Funktionen kennt as die der Präparierung des Gegenstandes ...'. (HA, p. 100). My gloss is that reason here is both utopian, public communication that organizes a collective agent as well as an unreflective instrument by which the individual organizes his or her exploitation of sensuous objects.

6. '(T]he contradiction between the pure versus the empirical reason' [Vernunft] can be resolved in the 'conscious solidarity of the whole group' (HA, p. 100).

7. 'Kann es [Verstand] für die Menschheit wegen des Formalismus der Vernunft auch kein notwendiges Vorbild abgeben ...' (HA, p. 120). My take is that the 'formalism of reason' disqualifies it from generating ideal models for humanity.

8. 'Sade's work, like that of Nietzsche, comprises by contrast an intransigent critique of practical reason, beside which even that of the total iconoclast [Kant] appears like a revocation of its own thinking' (HA, p. 113).

9. 'With the formalizing of reason, theory itself, in so far as it wishes to be more than an indicator for neutral methods of processing, becomes an incomprehensible concept' (HA, p. 112).

10. 'In der Seele sollte ein geheimer Mechanismus wirken, der die unmittelbaren Daten bereits so präpariert, dass sie ins System der Reinen Vernunft hineinpassen. Das Geheimnis ist heute enträtselt' (HA, p. 152). The sentence likens the superficial schematizing of popular perception by advertising corporations to the soul's intrinsic reliance on schemata in Kant's Critique of Pure Reason.

11. 'The first glimmering of reason, which emerges from such a [creative] drive and is reflected in the recollecting thought of humans, falls even on its happiest day on its irresolvable contradiction: the tragedy which reason alone cannot alter' (HA, p. 273).

Although my paraphrases are hardly definitive, 'reason' appears to be a zoo of contraries within a map, not just across different maps (LM, p. 17). Reason covers the actual psychology of historical individuals, the universalistic striving of social groups to transcend their environment, a primitive human faculty, formal pragmatics, the exalted self-reflection of Kant, bourgeois reason, mundane 
calculative reason 'as if' it were reason, reason as the classificatory schemata of pop culture, practical reason, capitalist reason, organizational reason, not to mention English translating in which the phrase 'a reason that' substitutes for 'cause'. The signifieds are not just scattered but irreconcilable: on one side they comprise unchangeable logic, objective necessity and universality and in reverse, they comprise what is subjective, contingent and culturally particular (Schnädelbach, 1981, p. 20; Joas, 1992, p. 264). It seems unlikely that counts of Vernunft point toward any core meaning (Velkley, 1989, pp. 167-178; HA, p. 250). In my view, semantic diffractions are multiplied (or perhaps 'get exponentially more complex') if one tracks across the pages-long German paragraphs any co-occurrence of Vernunft with ambiguous terms such as 'nature' (LM, pp. 15, 32). As Horkheimer and Adorno help us recall, the token 'nature' (near the top by sheer frequency) can mean either empirical appearance or essence, actuality or capacity, a state of affairs or that which is not expressed (HA, p. 16).

It seems advisable to reckon that sense obtains between two words only within unwieldy contexts of use, not in 'isolated splendor' (Kilgarriff, 1997; Geeraerts, 2010, p. 90; Tanney, 2013, p. 343; Stewart, 2015). For example, 'boy' and 'girl' may look like opposites, but in a passage in which both are contrasted to nonhumans, they acquire similar denotations (Travis, 2000, p. 226). Drawing likewise from the third most frequent pair in Table A2 (LM, p. 320), it appears at first that 'nature' may contrast with 'social'. But in Dialectic of Enlightenment nature also becomes the ground of the social (via the play of sexual urges) once formal reason undermines morality (Horkheimer and Adorno, 2002, pp. 89-92). The interworking of nature and the social varies further across the oeuvres of the Frankfurt School (Vogel, 1996, pp. 105, 151, 167).

Once upon a time, quantitative sociologists who were alerted to the dangers of primitive positivism assumed that concepts are not what we unproblematically observe via expressions, but are what we struggle to operationalize. Lee and Martin are perspicacious as ever when they write "We have simply made a class of assumptions of interpretive equivalence which we have not actually checked' (LM, p. 17). Consider why they cannot: scrutinizing whether word occurrences are equivalent leads us to their functioning within textual wholes. To validate words as indicators of a superordinate meaning is to categorize them like a coder and to fall into the same off-stage hermeneutic circle that Lee and Martin adduced is unacceptable for data production. Horkheimer and Adorno composed their 1944 work to show 'reason' conceals its antithesis (HA, p. 250), elegantly attesting that counts of 'reason' cannot exit from 'pastures of verdant complexity in which things can turn into their opposites' (LM, p. 21). The omission of semantic checks was necessary because Lee and Martin can broadcast the advantage of their method on condition they never glance at thin air below their feet.

By humanistic tradition a researcher who focuses on lexical analysis acknowledges the hermeneutic circle by exposing for inspection how a word is being 
taken to function within varying contexts. For example, the Jesuit priest Roberto Busa in the 1940s built a compendium of the metaphysics of presence across the opuses of Thomas Aquinas. Busa ascertained that combing for the isolated terms praesens and praesentia yielded fiddle-faddle. To appreciate what the pivotal phrase 'in the presence' was about, he needed to disambiguate different senses of 'in', exactly the sort of judgment computers are ill-suited to initiate (Busa, 1949, pp. 77-79, 87-101, 155-159; Gigerenzer, 2007, p. 98). '[A]ll functional or grammatical words (which in my mind are not "empty" at all but philosophically rich) manifest the deepest logic of being which generates the basic structures of human discourse', Busa wrote (1980, p. 83). Intellectual substance pivoted on the 'stopwords' that Lee and Martin by fiat discard as 'clutter' (LM 20). IBM eventually assisted Busa to produce a mammoth concordance from which dozens of maps like those of Lee and Martin can be extracted (www.corpusthomisticum .org). Yet to address substantive theological questions, the meanings of each graphic sign depended on identifying what in specific contexts of use fabricated its value. To this end Busa colligated these settings of usage, not bare words, as verifiable backup (Busa, 1949). 'A sentence has a global meaning which is not the pure sum of the values of its single components', Busa explained (1980, p. 88).

\section{Do Counts Measure Meaning?}

Lee and Martin scintillate when they show how counting delivers answers of some kind when texts can be treated objectivistically as word heaps. For example, Lee and Martin remind us that word frequencies have been used to attribute authorship to sections of the venerated Federalist papers (LM, p. 11). But that memorable illustration rests on exceptional conditions. It presumes: a control group of other texts whose authorship is incontrovertibly established and which reveal reliance on pet function-words; comparison works in the same genre produced at the same time; a small number of candidate authors (preferably two); and, to wit, conditions of falsifiability specified in advance (Craig, 2004, p. 287; Juola, 2006). Since these parameters are largely absent whenever we attempt a critical judgment of what a composition most instructively 'is' (LM, p. 5), Lee and Martin's reliance upon the forensic question of who physically moved pen on paper is inapt for rendering word counts plausibly determinative of much else. The disjuncture follows Thomas Kuhn's dictum that quantitative measurement produces findings only in the unusual circumstance that 'the scientist measuring knows everything but the particular form of the quantitative result he [or she] will obtain' (Kuhn, 1977, p. 198).

Consider another route by which Lee and Martin would have us decrypt counts as stand-ins for a composition. They argue that a text's failure to mention a previous thinker is preliminary evidence that he or she did not exercise much 
influence upon the writing (LM, p. 15). To me this example affirms instead why inferences can be drawn neither from word nor coding frequencies (Biernacki, 2012b, pp. 115, 131, 134). Everyone knows it is otiose scholasticism for an author to reference an important predecessor explicitly if the influence saturates most pages and the audience is already in the know. This is only to re-explain why Aristotle always neglected to reference his omnipresent interlocutor, Plato (Bourdieu, 1985, p. 41).

Suppose we go further than Lee and Martin did and count a name from their baseline, Dialectic of Enlightenment. Initially their litmus test appears correct, for Horkheimer and Adorno deploy the name of their predecessor Marx. But the reference occurs only in their allegation of the 'idiocy' of the ... Marx Brothers (HA, p. 168). Karl as a named figure is absent precisely because his reasoning is already on display through so many passages. To delve capriciously, Horkheimer and Adorno declare that the same 'equivalencies rule bourgeois justice as well as the exchange of commodities' (HA, p. 6); they emphasize 'the concrete labor conditions of class society' (HA, p. 43); and they invoke the extraction of surplus value by observing that 'one can provide for the subsistence of the manual laborers, who are used to serve the accumulating fixed capital, with the minimal portion of the working time over which the masters of society dispose' (HA, p. 45). In light of the frequent allusions, failure to refer to Karl himself affirms his influence is inestimably large. Incongruity between names and influence also arises if, for example, writers in lands regarded as peripheral either suppress or exaggerate references to their inspirations from the metropole (Waisman, 2005).

In reverse, high counts of a feature can drain it of significance (as with coding). When Saussure found that the mysterious anagrams he had detected in ancient literature came into view quite often, the phenomenon began to look chimerical (Starobinski, 1980, pp. 118-120). A count never endorses the centrality or marginality of a given ' $\mathrm{X}$ ' but paradoxically guarantees that whatever we 'take it as' can be turned on its head. For example, if British book reviewers in Griswold's sample seldom mentioned colonialism in their assessments of George Lamming's novels, should we conclude colonialism was implicitly fused under the rubrics of race; that colonialism was tangential to reviewers' reception of his work; that colonialism was so central to post-war Britain, it became too fraught to mention, Griswold's favorite and taken as obvious; or, finally, that its role was merely taken for granted (Biernacki, 2012b, pp. 15, 112-116)? No matter how ingeniously a researcher tries to measure operative mechanisms, a frequency stands for something only by a frame of reference projected from without (Biernacki, 2012b, pp. 143-144; 158 n. 19; Belluck, 2015).

Lee and Martin also call on Weber to suggest that word counts characterize conceptual dynamics. They take as solid the finding that Luther was the first to transfer Beruf from indicating a purely religious calling to include a calling from God that was this-worldly and occupational. For them Weber's insight into this conceptual change resulted from a 'word count (albeit of a simple kind)' 
(LM, p. 25). It seems to me their lexical example exhibits to the contrary how Weber drew entirely on inference from context, since Luther continued to use Beruf in its older senses as well. Mechanical tallies of Beruf in one opus versus another - even within one of Luther's writings, researchers have noted - remain trivial, for among Lutherans as well as Calvinists this single word continued to denote either clerical duty or the laity's summons to worship or worldly vocation (Schindley, 2000, pp. 128-140; Ascher, 2010, pp. 99, 106). Weber initially debated critics who denied Luther had innovated in applying Beruf to labor (Fischer, 1982, p. 13). Yet a consensus in Weber's favor has been reached (so far) by testing his hypothesis against more variegated situations for Luther's writing (Büttgen, 2004; Frey, 2008). The finding that Lee and Martin affirm as standing 'the test of time' depended entirely on the method that they would demote: expert plein air interpretation of a word embedded in contexts that have been enlarged and varied for retesting a hypothesis about its significance (Conze, 1972, pp. 493-495; Schindley, 2000).

\section{Shifting the Burden of Proof}

To my mind, Lee and Martin parry the difficulties in how they operationalize meaning with a fait accompli. Upon display their computation is 'prima facie evidence' with a commonsense decipherment (that is how most of us would interpret these numbers), so 'the burden of proof should have shifted' (LM, p. 17). They reinforce their advantage by warning 'It is not enough to point to the limitations and impoverishment in the procedures' (LM, p. 18). This is to plead that if word enumeration appears after the fact as somewhat fruitful, the only way for a skeptic to reject it is to exhibit it as completely wrong. This injunction may sound cogent if stringent, because starting from a verbal proposition it is grammatically possible to flip it into its negation. But there is no equivalent for a visual chart of numeric data. Imagining one could counter by showing the representation lacks any verisimilitude is a category mistake (Goodman, 1978, p. 132; Heintz, 2007). No muniments from the target text are fit for the task of 'proving' a cartogram fails to resemble its source (Goodman and Elgin, 1988, pp. 20, 111). Lee and Martin demand no less when they hedge that 'all sociological data are incredibly impoverished, and they are subject to all sorts of differential influences' (LM, p. 18).

To unrig the conversation, let me submit a counter-frame. In the 1960's Harold Garfinkel conducted an experiment to explore how people rationalize the importance of data that are neither sound nor misestimated - absolutely neither. ${ }^{2}$ As many will remember, he had students accept counseling from a psychologist

${ }^{2}$ My use of Garfinkel is indebted to Ramsay (2011, p. 62). 
who answered queries via an intercom. When so-called experts responded to a student request for advice about upcoming life decisions, they followed a pregiven sequence of truncated 'yes' or 'no' answers - empty chits. Garfinkel's setup brought to light how people make randomized, decontextualized 'data' immensely informative. The students' quest for cogency led them to acknowledge initially incomprehensible answers as lucid in light of contexts the students concocted by their own device. Students dreamed up standpoints from which to reevaluate inapt binary feedback as reasonable given imprecision in posing the initial question (Garfinkel, 1967, pp. 79-94). One may catalog how the yes/no output was in toto decisively simple, definitive, closed, delivered independently of a prejudicial framing, impoverished in expression and retrospectively transparent (by having followed a script) - most everything that Lee and Martin can verify to contrive it as 'data'. Accordingly, when I signal that Lee and Martin's formalizing is inadequate, I would rather not participate in the game of objecting that it is outright 'wrong', as they perhaps would like by assigning a 'burden of proof'. If a map is categorically unlike a text because all articulation of passages has been removed, I can scarcely assess how much the map is off target (Reed, 2011, p. 22). Best I can do is to point relentlessly to the fully existent text and with luck impress how the proposed representation is best not accepted as genuine mapping at all (Van Peer, 1989, p. 304).

Without explaining and demonstrating how a measurement taps into underlying mechanisms of our world, Kuhn (1977) once wrote, numbers produce no generalizations and 'almost certainly they remain just numbers' (p. 198). Extensive quotation with paraphrasing from the atomized texts strike me as a desideratum for making plausible a correspondence between metrology and meaning (Biernacki, 2012b, pp. 130, 137). We seek operational transparency in experience rather than mechanical transparency in the abstract. If Lee and Martin plumb the truth when they insist that sociologists 'have learned in enough cases, when we throw it [the data] all together, the important principles of the world will shine through', why should we not just as well trust coding as unearthing good-enough approximations (LM, p. 18)? Why do Lee and Martin laud counting as 'better' when they acknowledge that it introduces noise and when there were no checks for semantic equivalency (LM, p. 30, n. 12)? Skeptics 'would need to determine why, if our interpretation is wrong, we see the pattern in the data that we do' (LM, pp. 17-18). In the absence of a warrant that the map-making conserves operative structure or nomic regularity from the original, this is the same defense as that invoked for the reading of tea leaves.

To my mind, it would have been inconceivable for Lee and Martin to authorize a neutral medium by which to gauge the degree to which pairs of words have equatable meanings across the idiosyncratic thinkers of the Frankfurt school (Quine, 1951, pp. 29-31). Even when linguists share automated methods to seek the meaning of expressions, they arrive at significantly diverging definitions of the same words (Stubbs, 2007, p. 235). Computer scientists retracing the 
meta-logic governing their programs affirm there can be no protocol for arriving at a word's target reference(s) from multiple contexts of usage (Nordh and Zanuttini, 2008, p. 1282). Instead, analysts acknowledge each occasion of use as an anecdote for imaginative insight into an ideal verbal prototype, not just as a data unit standing in a series (Kolgarriff, 2003). Vocabulary usage strays in all manner of ways from conventional specifications (McKean, 2009; Geeraerts, 2010, p. 15).

German philosophers often intended to manifest to readers the distance between concepts versus material signifiers (Dubost, 2004, p. 231). Horkheimer and Adorno (2002) in particular said that clarity required one to disrupt words' sedimented meanings, for 'the more purely and transparently they communicate what they designate, the more impenetrable they become' (p. 132). As a remedy they favored disorienting condensations, like Kulturindustrie, a term whose originally estranging effect merged esthetics with manufacture. German critical theory therefore seems to discredit a method that assumes the object-material is composed of iterated 'technical terms' (LM, p. 29). Above all Horkheimer and Adorno adopted varied expressions such as 'the objectification of thought' (HA, p. 32); 'the mediating moment of thought' (p. 43); 'the universal movement of sovereign thought' (p. 52); in sum, so great a reliance on the German Geist, the Latin Ratio, or of 'the thinking through of thought itself' (p. 28) that there may be a zoo of vocabulary operating as paradigmatic for 'reason' if defiant toward the formulaic repetition on which counting relies. ${ }^{3}$ For interpreting focal texts, the consensus among some computer analysts of corpora is that 'frequency is irrelevant' (Teubert, 2005, p. 6).

The style of Horkheimer and Adorno dispenses another warning about counterproductive rationalization. Suppose word formalizing could carry some validity because computer scientists grasped the tactical system by which a social philosopher manages the divide between sign and signified in a work or genre. Nonetheless, high-powered authors adapt collective idioms in idiosyncratic ways, and this expresses itself by varying the signature style in which words mediate the expression of 'concepts' (Biernacki, 2012b, p. 123). Each genre of communication (or among elite litterateurs, perhaps each author's work) may require prior study to verify how counts tap into semantics, an issue that has led to great uncertainty about generalizing from what is extracted (Macleod et al, 2000; Craig, 2004, p. 286; Teubert, 2005, p. 4). Compared to registry of mere surface features, humanistic attempts to grasp underlying cognitive schemas or grammars of expression may offer more direct leverage for generalizing from specific texts or expressions to larger cultural patterns (Whorf, 1941).

\footnotetext{
3 'Further, the pivotal concepts here are ones of recognized philosophical import, and thus, like other "technical terms", are usually kept consistent throughout the translated text' (LM, p. 29); 'A semantic relational analysis based on copresence in semantic neighborhoods is most reliable when each concept's symbolic representation is consistent throughout a text' (LM, p. 29).
} 


\section{Parasitic Formalism}

Lee and Martin as marvelous raconteurs do return to how an actual text functions so they can more pointedly advise us of the hazards of humanistic text analysis. In a sparkling move, they remind us how Borges (1962) showed that verbatim similar passages, both starting with 'truth, whose mother is history', end up with divergent meaning due only to how Borges elaborately framed them with para-testimony (p. 53). I think Lee and Martin's point is to diagnose how investigators confront forbidding obstacles in reaching a consensus about subtle texts when they consider works as wholes. But the authority of their expert diagnosis rebounds toward two lessons subversive of their word tallying. They reach from an enigmatic text an adequately sound interpretation, not an unstable paradox. Second, their highlighting of context unintentionally demonstrates how their method of isolating words would not deliver the operative meaning here as they have established it (LM, p. 7).

Although Lee and Martin acknowledge with modesty that their program is not a self-sufficient substitute for humanistic reading (LM, p. 20), I cannot escape the impression that it is entirely parasitic. As we just saw, to critique contextual interpretation as suspect, they must reach their own authoritative humanistic appraisal of sources. It is equally contradictory for them to reason from a similar humanistic baseline to recommend scientistic formalism as trustworthy. To sight this second kind of dependency, it is enough to recall that Lee and Martin assure us that by their trials behind the scenes, the paragraph is the valid text unit within which to count word copresence (LM, p. 29). But how this interpretive decision was reached (and with which source passages) is less revisitable than some acts of coding. To open up this black box requires us to debate whether one huge heap of words represents a text better than another heap, a business no less problematic than coding. Were it even intelligible to engage in such a global discussion, it would hinge from the outset on humanistic reading for what seems most significant about the source.

To appreciate this second kind of parasitism in specific trials, turn to Lee and Martin's initial example for numerating word pairs co-present in paragraphs. To capture the semantic webs surrounding the concepts of 'system' versus 'lifeworld' in Jürgen Habermas' The Theory of Communicative Action, they turn their computer loose on his Chapter 6. But to make the resulting diagram speak, they do not turn to the source chapter at all, as would be necessary to show that their cartography intelligibly corresponded to the surveyed landscape. Instead, they excerpt a sentence from elsewhere, Chapter 8 , to vividly condense the relations between the conceptions of system versus lifeworld 'in Chapter 6' (LM, p. 16):

While the onset of modernity (and the move away from traditional society) has seen the decoupling of these two conceptions, late modernity has witnessed their reunification, in which the system's instrumental rationality 
imperatives "make their way into the lifeworld from the outside - like colonial masters coming into a tribal society - and force a process of assimilation upon it" (Habermas, 1987b, p. 355). The unification of the system and lifeworld is represented in the social-system-society-lifeworldaction pentagram clique ...

(LM, p. 16)

Contrary to their counting method, the paragraph from which Lee and Martin seize this excerpt does not contain the word 'system', although that is the megaconcept the extract is to explicate. Clearly formalizing does not avoid quoting 'tendentiously chosen other parts' to help interpret the whole (LM, p. 9).

In my view, 'a radical dumbing down of cultural works' instead degrades the clarity and testability of fit between the selected quote and the impoverished whole (LM, p. 21). Lee and Martin's drawing of 'semantic relations' is based on hundreds of instances from Chapter 6 alone (LM, pp. 15, 31), so it should finger extensive discussion. As I understand it, the first of that chapter's two parts is dedicated to separating system and lifeworld analytically. Then, best I can judge, most all the remainder uses this contrast to delineate not the unification but the uncoupling of system and lifeworld, the phrase that naturally comprises the heading for the chapter's second part (Habermas, 1987a, pp. 153-197). Does Chapter 6 primarily attend to this uncoupling with 'the onset of modernity', the analytic premise, or to the reunification in 'late modernity', the implication Lee and Martin foreground? Readers can decide for themselves or perhaps adduce why Habermas makes such a determination treacherous (LaCapra, 1983, p. 147). Either way, the lesson strikes me that Lee and Martin cast unification as verbally dominant for an extraneous purpose, that of matching the numericspatial unification they perceive in their pentagram.

That Figure 2 (LM, p. 15) 'does seem to trace the outlines of important connections made by Habermas in the course of his argument' (LM, p. 16) is an irresistible notion only because the numeric 'connections' open up a fill-in-theblank. ${ }^{4}$ Depending on what one excerpts from anywhere as exemplary, 'connections' can be envisioned as marking either analytic contrast, or hierarchy, or interdependency, or succession, or articulation of a lack of connection or, finally, as Lee and Martin underscore, 'reunification' (LM, p. 16; cf Empson, 1951, pp. 252-261). Since the numeric ties between 'system' and 'lifeworld' are supposed to capture the whole but can be glossed much as one wishes, Lee and Martin's method lets a researcher leverage as synoptic almost any tendentiously plucked passage with less resistance and less bother than humanistic exegesis of concrete waymarks. As one rapidly increases the corpus size to 'a huge range', allegedly the advantage of computation (LM, p. 20), the illusion of justification grows because a snatched verbal passage does the talking for ever larger

4 This figure can be found in the Supplementary Information. 
populations (Biernacki, 2012b, p. 144). The widening mismatch appears inevitable if, as Lee and Martin agree, we imagine what an aggregate denotes via an ideal-typical prototype, but our computer culls instances of usage independent of conceptual context (LM, p. 5).

What is requisite for accepting counting as simplification rather than invention? By repeating the term 'reality' for the sense of a text (LM, p. 20), Lee and Martin cast meaning as a fixed object to be reprojected into diagrammatic space. But if our own construals help comprise meaning in the first place, just as the identity of a canonical work historically drifts across audiences, no fixed base exists from which to ascertain that word counts condense rather than invent meanings compared to the would-be original (Kermode, 1975, p. 139). That is requisite for declaring a gain in 'verisimilitude' or would-be 'cost' (LM, p. 9). Lee and Martin do not determine what they are jettisoning or how it bears upon alternative results for a research community. Counting and coding are twins in how they occlude their independent creativity.

'[A]though an impoverishment may indeed lose information necessary for an 'interpretation' ... the impoverishment does not force any particular meaningfulness upon us', Lee and Martin write. 'We can use a map to go many places' (LM, p. 13). Correlatively, perhaps, Ramsay (2011) explained why text data are enchantingly labile:

If something is known from a word-frequency list or a data visualization, it is undoubtedly a function of our desire to make sense of what has been presented. We fill in gaps, make connections backward and forward, explain inconsistencies, resolve contradictions, and, above all, generate additional narratives in the form of declarative realizations. Like any reading, readings of imperatively generated results allege numerous outside contexts and prompt various forms of cathexis.

Ramsay (2011) is among those in the literary avant-guard for whom interpreting tables of word counts is recommended for accessing more imaginative associations (p. 57). Perhaps similarly to Lee and Martin, Genette (1982) wrote of this method of literary experiment more generally that 'The warrant of lucidity here is the purely "mechanical" principle of transformation ... nothing "tendentious" or premeditated' (p. 56). Ramsay (2011) analogously emphasizes how processing words independent of context is bound to conjure up otherwise inaccessible glimmers of significance (p. 80).

Lee and Martin's reliance upon Chapter 8 to explain what they formalized in Chapter 6 confirms how enumerating opens up poetic craftwork. They reach outside their text-as-object to find a more telling exemplar for imagining what is in the collapsed data. That understandable purpose is why so many coders highlight quotes from outside their sample to surmise what their data supposedly 
show is within the sample: the move accesses more acute prototypes (Biernacki, 2012b, pp. 146-147, 149; LM, p. 5).

Conversely, the closer one appears to hew to the formalized data, the more unstable and uninformative the interpretation. From the central 'pentagram' of system and lifeworld counts (as well as from mapped ties to the outskirts) we are supposed to envision 'a merging of two concepts that is pulled in two different directions' (LM, p. 16). But have another glance, and I fear one just as aptly announces the opposite: 'a splitting of two concepts that are merged', I would say, especially in light of Habermas' critique of the conflating of system and lifeworld in Chapter 6. The figure to me morphs toward logically opposite alternatives, overtaking therefore Wittgenstein's legendary Duck-Rabbit in multistability (Wittgenstein, 1958, p. 194; Biernacki, 2012b, pp. 13, 128-129). As indicated by Lee and Martin's need to convert the numbers into a central 'pentagram' to characterize them, interpretive largess is magnified whether one imagines oneself to be processing the 'pictorial representation' or numbers alone (LM, pp. 19-20; cf LM, p. 13). ${ }^{5}$

Lee and Martin are at their best in arguing for swifter 'closure' among sociologists 'unwilling to wait for the second coming to resolve interpretive ambiguities' (LM, p. 17). My estimate is that rather than anchoring interpretations, the mute ciphers help them run loose. In the fractured numbers, no verbal relations, propositions or sequencing remain to guide construals. We fabricate a gloss from scratch. In particular, after the illocutionary force of the utterer is dissolved by the counts, static 'connections' are stripped of the instructive footing of a pragmatic agent. Lend an ear to how Lee and Martin encapsulate the diagrams via nouns rather than verbs ('reunification' or 'overlap'), rely on the passive voice, or suggest, as above, that dominant numbers are actants frozen in the act of merging or getting 'pulled' (LM, p. 16). I doubt 'closure' of debate, like accepting the flip of a coin, is an end in itself (Biernacki, 2014b, pp. 182-183). What can technocratic closure amount to other than choking by dictatorship a language community in which meanings are constantly critiqued and renegotiated?

My hunch is that Lee and Martin transform 'meaning into facts' to hypostasize 'facts' as existing in tables cordoned from the rest of the world, a corrective to illimitable contexts (LM, pp. 8, 10). The numbers assure us we know the 'key features of a text when our normal interpretive mode would be to obscure facts' (LM, p. 10). By their analogy to a geographic map, 'we can show and not simply tell' since the alleged condensation is a " "reduced-size" whole' (LM, p. 14). But an assortment of sums cannot 'show' us a coherent verbal whole and so cannot 'force an interpretation on a disbeliever' (LM, p. 9). The crux of rigorous cultural inquiry instead is to aid examination of how facts enter our experience only as we

${ }^{5}$ Cartographic objects or maps differ from other diagrams because they are 'spatially conceived' (McCarty, 2004, p. 262). 
select a particular frame of reference for their context (Weber, 1949, p. 110). The more we carry on as if we espy facts in our tables, the less we ponder how our own shuffling of contexts makes available any perceived fact for treatment (Kuhn, 1970, pp. 120, 126). If in humanistic interpretation we admit that adjudging up front, we do not reify results by letting the augury transpire behind our backs (Kermode, 1975; Guignon, 2002, pp. 278-279, 282-283). Since a text's makeup is symbolic and construed, its emergence in experience depends on the kind of perspectival choice by which scientists integrate or recolor large swaths of phenomena at once (Weber, 1949, p. 112; Kuhn, 1970, pp. 128-129). To my mind, for Lee and Martin to conceive that lexical pairs such as 'reasonnature' potentially imply countable unit-meanings or 'concept maps', they must covertly impose a stereotype on the components (Murphy and Medin, 1999).

Lee and Martin strike the right scientific chord in putting their method forward as a tentative one up for trial (LM, p. 17). To merit pursuit, I think the method should launch and vindicate bold conjectures. It strikes me that even the formalizing that Lee and Martin present as fresh or unexpected probes less and ratifies less than quite ordinary reading of Frankfurt School works (Hall, 2012). For example, by their reckoning 'it is Honneth, not Habermas, whose concept map (of his early work) agrees with the approach of Horkheimer and Adorno.... focusing on the subgraph of each that is tied to the concept "reason", (LM, pp. 18-19). This summation is barely news, since as many know Habermas published extensive commentaries to distance himself irreconcilably from what he called Horkheimer and Adorno's surrender 'to an uninhibited skepticism regarding reason' (Habermas, 1987b, p. 129; cf Holub, 1993, Honneth, 2000). Introductory handbooks explicate this parting of the ways regarding Vernunft with greater acuity than Lee and Martin's mapping ever could (Bremer, 2001, p. 846). In addition, if one opens the book by Honneth that Lee and Martin chose to atomize, The Critique of Power, one can scarcely avoid discovering that in its first third, Honneth applies himself to resuscitating Dialectic of Enlightenment as a crucible for critical theory (Honneth, 1991, pp. 3-96). It is in relation to this founding work that Honneth organizes his discussion of Foucault as well (Honneth, 1991, pp. xv,198-202). Since one cannot weigh competing interpretations of tallies without crowning humanistic reading of the sources as independent arbiter, there is no ground by which to attribute greater legitimacy to coding either by itself or in conjunction with humanistic reading. Attentive reading on its own offers equal justification for concluding Honneth is more closely affiliated to Adorno and Horkheimer than is Habermas.

The parasitism of counting may explain the peculiarity that Lee and Martin assert no more than that 'most' people would happen to decrypt a tally their way (LM, p. 17). They never engage textual evidence supporting alternative readings, as would be required to illustrate how counting encourages consensus by showing rather than telling. To the contrary, Lee and Martin grant pluralistically that anyone could reasonably demure from their preferred interpretation of a tally in illimitable ways, 
and there they let the issue rest (LM, p. 17). By their Frankfurt School examples, I see Lee and Martin in practice reaching only for intersubjective understanding and orderly reconsideration (my standard for coding), not for convergence and closure, the benchmark by which Lee and Martin dismiss coding but which they do not seem to uphold in trials of their own method (LM, pp. 19, 30).

Of course Lee and Martin are attuned to the possibility that their cartography will feature 'neither novelty nor depth' (LM, p. 16). Then the current bonus from their method, I dare say, is the conviction we acquire from seeing the numbers and commonplace readings happily line up with each other (LM, p. 19). Unfortunately the logic of multiple indicators is only a circular guarantee, like that of the Azande or of some mixed-methods researchers, unless Lee and Martin demonstrate that plain source reading and interpretations of word parceling are generated independently (Biernacki, 2012b, p. 15, 2014b, pp. 184-185). But that seems infeasible: humanistic reading is mobilized to justify the paragraph as the gauge of 'neighborhood' proximity as well as to interpret any particular sub-count (LM, pp. 29-31). Moreover 'perverse' results from counting, rather than standing on their own, are said to disqualify counting (LM, p. 17). It is reasonable for Lee and Martin to leverage their numerating as support for comprehending 'Honneth's work as a return to some of the first generational principles' (LM, p. 19). Yet it is easy to envision why quantifying does not pin down a rendering of conceptual postures. Imagine that the mapping appeared to allege that the greatest 'overlap' was instead between Habermas and Honneth - that opposite result, too, receives verbal backup from culminating reflections in the sources (Honneth, 1991, p. 202). When the discursive filiation and contrast between theorists is qualitatively multi-layered, but numbers flatten the signal down to quantitative 'overlap', the numbers deliver no adjudicable propositions about theorists' texts-as-communication.

\section{How Did the Illusion of Mapping Originate?}

Even with Lee and Martin's thoughtful caveats, we still should ask which two objects in their trial analyses play the role of the Grand Canyon landscape and of its map per their Figure 1 (LM, p. 12). ${ }^{6}$ With the geographical map, Lee and Martin recount, 'we can plan a hike down the Grand Canyon in close detail while remaining in our living rooms' (LM, p. 12). The isomorphism between map and landscape is uniform across every region and precise enough that we can use the map to estimate distances and changes in elevation (LM, p. 13). In genuine cartography there is a symmetry between the landscape and the map as follows: not only does the landscape translate forward to the map but the map can be systematically translated backward to an approximate duplicate of the landscape

6 This figure can be found in the Supplementary Information. 
(such as a three-dimensional model out of clay, let us say, that many would recognize as the Grand Canyon). For Lee and Martin's milieu of word mapping, in which we might by analogy assume 'the impoverishment is hermeneutically indeterminate' (LM, pp. 12-13), we do not know what to make of the map of word counts as we would know how to use a genuine land map. We cannot translate backwards from an outputted word map (LM, p. 15) to a verbal argument that is recognizably The Theory of Communicative Action. The isomorphism across regions is variable and the symmetry in moving from land to map or from map to land vanishes. Nor does the map help us navigate through Habermas' prose 'in close detail'. An opus cannot play the role of a fixed object (analogous to the Grand Canyon) in relation to a map because two entities of different natures, physical book and intelligible text, are being swapped in relation to the map. Translating forward from landscape to map, our computer treats the book merely as marks on a page. Translating backward from map to landscape, what the map supposedly portrays is an ontologically different entity, a meaningful composition. That I doubt it can do, because it has removed the text's conceptual coordination of parts.

Pure and simple, Lee and Martin are pleased that their word counts 'worked fine, first crack off the bat' (LM, p. 17). It is difficult to conceive how they adjudicated this matter if their inspiration is a land map that is also 'bermeneutically indeterminate' (LM, p. 13). Their method would fail to do justice to a text, they speculate, if 'after performing our formal analysis, we decide that it gives us a perverse interpretation' (LM, p. 17). How could that circumstance arise in reality? A table of ciphers relies on $u s$ for its verbal sense, so it would seem a bit delusional to conclude that it 'gives us a perverse interpretation'. With strippeddown information, Garfinkel and Ramsay indicate, we accommodate potential anomalies to ensure cogency never cracks.

\section{Structural Composition}

Explicating a text pertains to the contextual senses of words. To go further to elucidate a text requires one to determine larger organizing units of the discourse that are not explicitly reported as such (Beardsley, 1958, p. 401). A coherent work 'answers to the ideals of a cognitive system: insofar as possible it is self-engendering, self-sustaining, and self-sufficient' (Rescher, 2001, p. 46; Wittenberg, 2001, p. 194). For that purpose it bears narrative integrity: questions develop out of antecedent premises, meta-commentary coordinates this enchaining, illustrations of principles work by subnarratives, and so forth (Burke, 1968; Galay, 1977; Halliday, 2002, pp. 226-227). As Lee and Martin are aware (LM, p. 3), often 'clarity does not spread from the parts to the whole, but from the whole to the parts' (Belaval, 1966, p. 91). 
Nonetheless the imputing of an overall message, the whole, is exactly what Lee and Martin want us to defer until after quantifying has tossed out the text's own knitting of parts (LM, p. 14) - which I fear is to miss the train because we erased its stations. The canonical principles of scientific mapping include: (i) preserving relational properties even if object descriptions are elided; and (ii) more specifically, maximizing systematic relational structure by higher-order principles for coherence and for the inferential power of the mapping (Gentner and Jeziorski, 1993, pp. 449-450). As Lee and Martin explicate with their honesty, 'it is worth emphasizing that the simple maps used here have no structure' (LM, p. 20). But it is evident to many that communication elucidated via discourse 'is given in and through the structure', not through information (Ricoeur, 1981, p. 138). The proof, as censors know, is that surgically excising substantial portions of a text recasts its conceptual makeup (Genette, 1982, p. 263).

Humanistic traditions focused on the relations of parts to a whole can fuse the task of understanding the structure with the rigor of explaining it scientifically (Ricoeur, 1981, pp. 152-157; Biernacki, 2012b, p. 137). In Morphology of the Folktale, Vladimir Propp detached structural functions (such as 'interdiction' and 'departure') in stories' plot overall from the characters who performed them as well as from the manner in which the maneuvers were fulfilled (Propp, 1968, p. 66). Propp uses his models as ideal types to illuminate the necessary sequence of events as a global configuration. Then, looking downward to parts, Propp lends coherent purpose even to narratives' minor details, such as a vixen's request to have a hen fried for her with butter (Propp, 1968, p. 41). This concreteness matters when researchers in the structuralist tradition that Propp exemplifies competitively assess the reliability and relative usefulness of a formalization. They are vulnerable in addressing previously unnoticed details and the totality of a canonical work such as the Oedipus myth (Turner, 1969; Propp, 1983, pp. 110-111, 118). In all rigorous inquiry, the moment of formal modeling is only preliminary for returning to the phenomenon afresh. This is necessary to scrutinize the explanatory pay-offs: a model's realignment of experienced facts, suggestion of new mechanisms, consistency with other models or on the other hand, slippery application and incompleteness (Lakatos, 1970; Marschall, 1985). This juxtaposition of model with text seems more akin to science as conventionally understood than Lee and Martin's blind, unidirectional version of formalizing (Herman, 2002, pp. 128-131).

From my standpoint, Lee and Martin fail to show how their numerating can digest detail systematically or how it clarifies the eloquence of a text. That is why their projections into a 'reduced space' alarm me as subverting scientific norms. If a diagram of counts paralleled the taxonomy of texts, it would also direct our attention to instances of poor fit. But lacking structure, the word counts offer no map-to-landscape homomorphism of a kind that lets us discern anomalies. Not once do Lee and Martin render a local failure in their method, so talk of an 'allowable margin' of misestimation seems imponderable (LM, p. 13). 
Genuine cartographers of land, confronted with inevitable distortions in their models, have been prompted to recast their projections (Monmonier, 1996). Lee and Martin admirably try to remain scrupulous by banning attempts to improve map-to-landscape congruity. As they take up the matter, formal mapping procedures 'that are adapted too many times' for satisfactory results are corrupted by backstage interventions (LM, p. 17). Certainly researchers may opt to avoid accommodating the data by ad hoc fudging (Lipton, 2004, pp. 181-182). But fiddling with a procedure seems to be in order for initially tuning it as an instrument. At the outset, in fact, tinkering to weigh the results for relative 'goodness of fit' would help verify what representational function the formalizing serves at all.

\section{Prejudicial Spatialization by Numeric Counts}

Once we believe a display of atomic words captures core 'facts' about a text (LM, p. 10), our work from visual and mathematical cues steers us toward interpretations based on spatial metaphors of 'overlap', 'circling around' or 'magnitude', as the hypotheses submitted by Lee and Martin indicate. The spatial spin intrinsic to the notion of cartography leads us to proposals that look informative from a quantitative perspective but are verbally vacuous (Biernacki, 2012b, p. 138). Consider Lee and Martin's explanation of the break between Erich Fromm and the Frankfurt School. As I understand it, Lee and Martin determine in selected works by the insider Herbert Marcuse versus those by Fromm that among the hundred most frequently occurring descriptors, about a third of them are shared by these theorists. This fraction they call an 'overlap' score (LM, p. 33). To assess this datum, they determine that the same 'magnitude' of 'intersection' happens to approximate that found between several of Fromm's own works. On the basis of these counts they infer that 'it was, it seems, this overlap, and not difference, that caused Fromm's expulsion' (LM, p. 19). Of course it would be useful to check the sources for how expression of 'overlap' could have 'caused' the break.

Lee and Martin do not return to the texts to check, perhaps because it would have been pointless. A scaling of 'thematic agreement', an analytically slippery term from the get-go (Hawthorn, 1994, pp. 299-300; Lamarque, 2002, p. 298), may impart something with respect to numeric tables, but in relation to an interworked text it is so malformed a proposal as to be either undecidable or automatically correct - anyone's choice (cf Rieder and Röhle, 2012, p. 79). Where is the contrast group that shows us intelligible debate could possibly avoid circling around 'the same basic concept structure' (LM, p. 19)? Converting insights from the kingdom of numbers into the verbal realm suggests to me the numbers knock us off course. 'The major obstacle', Roberto Busa discerned long ago, "lies in the "semanticity" of "words", which is deeply different from that of 
numbers and symbols' (Busa, 1980, p. 88). Numbers seem to rob us of our wits: how could we forget for a moment that even if an 'overlap' in vocabulary were mathematically huge and perfectly registered conceptual similarity, it could just as well turn out that differences alone were intellectually consequential? Quantitative reasoning about 'magnitude' in a diagram led Lee and Martin to take it as commonsense that whatever is big and frequent marks what is most important for explaining a specific communicative consequence. They must call on that decoding heuristic to maintain in principle there can be a commonsense 'seeing' - otherwise exiguous quantities on the margins open up so much ingenious play that 'seeing' the whole becomes too obviously an ongoing venture.

To determine if the objectivistic perception of an 'overlap' bears weight, turn to the bitter exchanges between Fromm and Marcuse concerning Freudian revisionism in the journal Dissent from 1955 to 1956. Lee and Martin do not appear to have felt their way around in this rich quarry. Their quantitative method directed them to larger, less relevant corpora. In Dissent nearly every utterance of Fromm and Marcuse points toward unrelenting disagreement over Freud's premises and implications (Fromm, 1956, pp. 82-83; Marcuse, 1956, pp. 79-80). Yet no verbal expression could ever be retrieved to disprove the geometric-numeric metaphor of some implicit 'overlap'.

More instructively, once we pose Lee and Martin's question 'Did Fromm use Freud one way, and the other critical theorists another?' (LM, p. 19), the answer depends less on frequencies of isolated descriptors than on how writers articulate Freud's tenets within a complete architecture. Fromm and Marcuse insert Freud into a broader issue, that of determining whether the love we experience in our repressive society is too deformed for intimating to us the eventual shape of human fulfillment (Fromm, 1955, p. 347; Marcuse, 1955, pp. 233-235). When Marcuse closes with the charge that Fromm and alleged affiliates have abandoned the source 'from which psychoanalytic theory drew all its critical insights' (Marcuse, 1955, p. 239), his condemnation speaks against Lee and Martin's presumption that the counting 'suggests a very strong thematic agreement between Fromm and Marcuse as to what 'Freud' means for critical theory' (LM, p. 33, emphasis added). Marcuse's (1966) famously polarizing sentence, reprinted as the closing flourish in one of the larger sources that Lee and Martin atomize, seems more legible and resounding than numeric projections (Marcuse, 1966, p. 274). Fromm came up with an equally blanket rejection of Marcuse's approach 'to what "Freud" means for critical theory'. He infamously wrote that 'Marcuse's position is an example of human nihilism disguised as radicalism' (Fromm, 1955, p. 349).

These issues regarding the normative footing of critical theory surpass Freud and advise us the debaters may have used him as a pawn in ethical posturing over responses to an inhuman civilization. Some historians surmise the controversy stemmed from this surrounding issue, which lingered from the two theorists' conduct during the war against Hitler (cf. Friedman, 2013, pp. 196-198). Bringing another context to bear, choices regarding Freud may also have served 
as signals to garner resources from Horkheimer's institute (McLaughlin, 1999, p. 128). At least the polemics in Dissent betray how corpora broken down into 'data' remain peripheral for calculating what 'caused' the break. Whether formalizing helps referee interpretations is the pertinent question. Conjuring with multiple contexts to seize the whole is inescapable in human inquiry. Whatever Lee and Martin wish to make of contexts for reading Paul de Man's remarks (LM, pp. 7-8), this fettle remains in elucidating their word sums.

With Dissent as an initial distillation, I have tried to adumbrate how targeting briefer sources, if less appropriate for counting, may be better suited for chiseling context-appropriate questions. Examining how the expression of ado about Freud in the original was verbally subordinate to higher-level issues guides us to wider fields of evidence for meaning-changing contexts (LaCapra, 1983, p. 117). Lee and Martin are open and acute in acknowledging a continuing need for humanistic lection (LM, p. 20). But the malformed questions and answers they derive from the Fromm-Marcuse computation reinforce my impression that laboring with numbers cannot add value.

\section{How Historical Texts Address Sociological Questions}

The type of research puzzle that Lee and Martin's formalizing addresses seems to be that of deciphering most securely or fundamentally what texts report. Only peripherally do Lee and Martin address the question of how texts help to explain social action apart from intellectual history. The limited job they assign their word counts is predictable, since disembedding words for counting leaves us with bare constatives. When we make texts talk as 'facts', what they seem to do is to describe in an indicative voice (Hobbs et al, 1993, p. 69).

Lee and Martin's own sources indicate how restrictive a key this is for appreciating discourse (cf Feldman, 2006, pp. 8-9). The weaving of myth and literature into Dialectic of Enlightenment and its estranging language suggest to me that the work is more than a set of propositions about social mechanisms. It is designed to perform a kind of interpellation or dare. As Honneth (2000) has remarked of its 'mode of communication', the work 'does not pursue the goal of recommending another interpretation of the history of the human species from a social-theoretical perspective, but rather provokes a changed perception of parts of our apparently familiar lifeworld so that we will become attentive to their pathological character' (p. 124). It is held together in the form of a speech act, similar perhaps to a courtroom accusation in a democratic community that would open up deliberation over appropriate norms for humanity.

Capturing variously nuanced types of illocutionary force, by which a text may accomplish the act of promising, requesting, commanding, wishing or another kind of behabitive, is the most immediate way in which interpreting a text 
explains social action. This illocutionary force, for linguists an elemental constituent of communication, is critical for reading texts as a drama between social players or antagonists. But this force is not comprised of words that report concepts, as in Lee and Martin's method (Grice, 1957). Recalling the legacy of Erving Goffman's Frame Analysis (1974) suffices to recall how a text's effect depends on whether players recognize it 'as' a mere joke, 'as' an empty threat, or 'as' a real declaration. In historical sociology of law, for example, retracing how words uttered in a pragmatic setting become action that creates promissory obligations is basic to explaining the uneven development of institutions of contract (cf Pakkala-Weckström, 2008; Biernacki, 2014a).

The keying that comprises a text's illocutionary posture is contained less in what is said than in how precisely it is designed to be decoded, which requires sociologists, like the social actors themselves, to use the text's original composition, not a quantitative simplification (Vanderveken, 1990, p. 23; Skinner, 2002, pp. 123-124). In A Treatise of Human Nature, David Hume rarely mentions God, so by Lee and Martin's method, Hume's stance on God can scarcely be revelatory of the whole. Yet Paul Russell in The Riddle of Hume's Treatise tried to offer a more thoroughgoing reading of the opus by hypothesizing it is configured to display why God must be verbally shunted to the side. The illocutionary force is that of perfected blasphemy, because the Treatise performatively enthrones the principle that God is not deserving of honorable mention. Although Hobbes largely shared Hume's secular outlook and believed like Hume that God was inconceivable, he did not sideline the word 'God' to carry out the act of making Him totally incidental (Russell, 2008, pp. 97-98). With Lee and Martin's focus on counts of what 'is', God could not be both beside the point and central to the organization of a text - yet we can see why, according to Russell, Hume's illocutionary framing logically made it so.

Of course a grand illustration of the challenge of using texts to make conduct intelligible was passed on to us by Weber's contested Protestant Ethic. To try to define the unique effects of Calvinist-inspired religious ideals, Weber identified their partial similarities to Catholicism as well as to Lutheranism. The doctrine of predestination, for example, 'was by no means strange' to Catholics, whereas Richard Baxter, Weber's (1958) concrete paragon of the Puritan, diluted that very doctrine in his writing (pp. 227, 232). Weber's (1958) argument hinges less on uniform expression of belief via texts, therefore, than on whether the texts disclose how believers may have been encouraged to pursue signs of their individual salvation (p. 111). From his interest in explaining the rise of an ethos that he came to call 'this worldly ascetism', Weber (1958) hypothesized the emotional implications of Calvinism's constellation or 'system of forces' as a whole (pp. 109-117). To refine the illocutionary force of this system, Weber highlighted the character of action it recommended given the organization of free labor by rational calculation in a market. Switching from this economic context back to the texts, Weber (1958) found Puritan writers discussing their relation to 
God as profitable trade for a bank account, showing how theology served as implicit advice for self-help although this violated its formal propositions (p. 238). Such a productive circuit of appraisal between texts and the context of writing and action can transpire only if the evidence on both sides of the equation is figured concretely (White, 1999, p. 56).

No matter whether Weber misestimated historical truth, this locus classicus also reminds us how tacking back and forth between text and context informs all interpretation when we use it to explain social conduct (Darnton, 1984, pp. 75-106; Gladdis, 2002; Skinner, 2002, pp. 128-157). More specifically, to explain conduct by reliance on a schema for cognition or evaluation, we have to explicate how the agents have actively appropriated it and put it to work, a task that requires us to trace how they creatively readapt schemata to respond to varying contexts (Biernacki, 1995, p. 494 n. 43; Biernacki, 2012b, pp. 153-154). Word counts and aggregate trends in corpora are unhelpful for this purpose because they do not let us track with compelling detail the alternatives and the selection by which an agent meshed conduct with context (Skinner, 2002, p. 119; Walton, 2004, p. 241).

\section{Summing Up: Word Counting as a Dead End}

Revisiting each of Lee and Martin's trial runs instructs us that word counts are too simplified and circularly parasitic to improve hypothesis tests of textual functioning (the domain of justification) and too quantitatively abstract to help articulate constructive hypotheses (the domain of discovery). I feel indebted to Lee and Martin because their radical experiment lets me sum up why I think separating the moment of interpretation from that of data generation is not a possible agenda: (i) every supposedly interpretation-free registry of words starts by imposing its own hermeneutic architecture and mechanisms of signification; (ii) meaning is not preexistent in our word tables as 'key features' or 'data'; (iii) for historically specific questions, success in quantitatively processing one author's work is scarcely generalizable for other authors or genres; (iv) isolated words or lexical pairs are not expedient parcels of meaning; (v) the validity of numeric counts is parasitic on stable humanistic reading of the texts from which they derive; (vi) the numeric geometries and 'semanticity' set up by quantitative results do not translate back to the verbal realm; (vii) numeric data do not offer independent indicators that can aid interpretation, because what they say is parasitic on humanistic interpretation for choosing a context by which to construe them; (viii) separating quantification from interpretation does not make interpretation more transparent but does make it more arbitrary; and (ix) word counts do not aid us in explaining human action. To my mind, Lee and Martin, like many in the 'digital humanities', hint that we should grant word parceling a 
longer incubation period during which it may eventually 'surprise us' with its fruits (LM, p. 20). Whereas Lee and Martin advise against 'waiting' indefinitely in matters of humanistic judgment (LM, p. 17), I see them counseling almost the opposite for their version of science.

\section{What is Humanist Interpretation?}

Lee, Martin and I share the predicament that our two major signposts, science and humanistic interpretation, are notoriously difficult to define even if they appear as founts for appraising inquiry. That dilemma is perhaps what led Lee and Martin to associate their cartography with science cast in the image of Bruno Latour's studies (LM, pp. 5, 14, 23). Latour of course typifies scientific practice as an endeavor to invent artifacts that attract and link allies as 'enlisted interests' (Latour, 1987, p. 122). Latour furthermore advises sociologists to avoid considering whether formalizing actually yields knowledge (Latour, 1987, p. 258). To begin cribbing Alistair MacIntyre a bit, by following Latour it seems Lee and Martin end up taking sides in the ancient philosophical quarrel that began with the sophists. Is it important for the inquirer to achieve genuine knowledge, or is it important only to be thought by others to have gained such? Adopting Latour's recipe for how people come to act as if a formalization comprised science in effect 'involves the most extreme of value commitments' (MacIntyre, 1971, p. 278). It champions the trappings as what we should pursue in life.

May we do better at specifying standards of judgment for humanistic interpretation (Hirsch, 1967; Griswold, 1987a, p. 27; Eco, 1994, pp. 60-61)? For its norms I would start with an interpretation's systematizing power. That is its ability to integrate with economy the details of a text or of a pattern of action. By this principle we examine first whether the interpretation processes questionable features, obscure passages or other oddities so as to transform them into contributing and necessary components of a coherent account with a minimum of assumptions (Rescher, 2001, pp. 65-76). In this endeavor we may also test coherence with relevantly sifted counterfactual reasoning. For example, supposing an element were to take a different guise or were absent, does the proposed changeover disclose why the functioning of the work would be impaired (Jameson, 1981, pp. 246-247)? Out of what ulterior concern might polemical authors fail to adopt an otherwise potent line of reasoning at their disposal? This norm of coherence-seeking is the ground even for positing that works are partially incoherent. Deconstructionist arguments or those accenting how texts subvert a notion of an organic whole all assert determination of meaning by this criterion of coherence precisely to exhibit how a text can be appreciated as operating in multiple or self-contradictory keys (de Man, 1979, pp. 11-12). Even Stanley Fish's calculated and outlandish readings are not entirely fanciful, for 
they work upon us only in so far as they come close enough to the text's setup for us to entertain them initially as possibly right (Abrams, 1989, pp. 286-287; Pettersson, 2002, pp. 218-219).

It is sometimes overlooked how Weber in The Protestant Ethic elaborates his case via interpretive consistency. Weber emphasized to his critics that he had traced more than ascetic Protestantism as a variable whose effect was funneled through the shaping of believers' interest in salvation (Weber, 1982a, p. 168). In place of such a narrow flow, he said he aimed to show instead how the construct of this-worldly ascetism accounted for people's action across diverse arenas because it inculcated a unified 'habitus' or a 'lifestyle founded on the unity of the person' (Weber, 1982b, pp. 297, 318). Weber used his sifting of Puritanism to decipher not just the character of economic conduct, but uncanny patterning in family procreation, in styles of consumption, in forms of recreation, as well as in the character of artistic and scientific pursuits (Weber, 1958, pp. 167-171, 263). Theological clues illuminated efficiently how these subtly colored dimensions of practice functioned of a piece (Weber, 1982b, pp. 305-306). Without a coherent interpretation of a complete type of human being (Weber, 1982b, p. 303, 324), Weber's imaginative guessing scarcely pays its way.

Achieving this interpretive coherence, Weber (1958) wrote, is not to cocoon texts but is 'in a certain sense doing violence to historical reality' (p. 233). No 'loving hands' here (LM, p. 3)! Our hypotheses about the whole are selfconsciously perspectival, and they deepen insight only when we set them in tension with the complexity of the historical originals (Biernacki, 2012b, pp. 144-151). To borrow from literary study, Eve Kosofsky Sedgwick in Between Men is explicit about her reliance on a reinvented model of love triangles to discern patterning across Shakespeare's sonnets, Wycherly's Country Wife, Sterne's Sentimental Journey, and other works up to the Victorian era. 'The triangle', she wrote, 'is useful as a figure by which the 'commonsense' of our intellectual tradition schematizes erotic relations, and because it allows us to condense into a juxtaposition with that folk-perception several somewhat different streams of recent thought' (Sedgwick, 1985, p. 21). The 'as if' model digests a spectrum of works in which pairs of men define their their erotic negotiations with each other by using relations to a woman as a contrast term (pp. 45, 157). The model intimates historical transformation in how sex is related to power from the sixteenth to the nineteenth century (p. 27). Sedgwick's range attests that thick description can sustain rather than weaken a generalizable story about cause and effect (p. 202). For setting a model in context requires an analyst to equip it 'to discriminate between radical, primary and determining transformations of those relationships and what are only secondary, superficial, or local changes in them' (White, 1999, p. 51).

We therefore arrive at a second heuristic of the humanist approach, that of weighing how broadly an interpretation of a text takes in the surrounding environment, such as its intended social impact, its position in an author's trajectory of writing, openings to relations of power, its bearing on how a 
community of discourse functioned or illumination of idioms in a broader culture. There can be no a priori axiom for trying out an invigorating context (LaCapra, 1983, pp. 35-71; White, 1999, p. 51). Ironically, one of the purposes of, say, an early modern scientific treatise may be to reify the distinction between context (society) and scientists' own doings (pure, natural science). Then for a productive interpretation we seek a perspective from which to demystify the separation of text and context that was generated in the first place via our influential textual material (Zammito, 2004, p. 177). In any event, records of critical discussion counsel us that weaker interpretations can be put into question or pressured into revision the more comprehensively they must contend with variegated features of the environment (Tarcov, 1988; Jay, 1990). Judging relevant context proceeds as does reading any document. When J.G.A. Pocock reconsidered Thomas Hobbes' opaque and often sidelined religious chapters in Leviathan, he was able to explain how they comprised for Hobbes' audience a 'tactical thrust' against presbyters and religious enthusiasts who might claim that the workings of salvation authorized political action in the present. Once Pocock (1989) unearthed this implication for seventeenth-century readers, he was also able to specify the internal workings of nominalism in Leviathan's other chapters more precisely (p. 187).

Finally, in my vision sociologists should assess the ramifying power of an interpretation. That is to ask in addition: does it pay its way by increased sophistication and depth of insight across a manifold of works or genres of action? By this principle we do not gauge a theory's immediate range, but its internal resources for reactivating inquiry and for progressively elaborating upon its suppositions (Kuhn, 1970, p. 31; Reed, 2011, pp. 20-21). In literary study, exalting this criterion fueled the rise of 'Theory' that is widely acknowledged to have born uneven effects (Corral and Patai, 2005). Yet many investigators have reread documents to advantage by using conspicuous speculations as all-consuming as those of Foucault, Freud or Marx. In The Family Romance of the French Revolution, Lynn Hunt made use of Freud's extravagant Totem and Taboo only as an ingenious construct, but that propelled her sighting of conflicts over patriarchy and brotherly fraternity that were uncannily expressed across a range of documents (Hunt, 1993, pp. 59, 60, 62, 70, 73). Deployed as a hypothetical frame of reference, Totem and Taboo let her explore the development of new kinds of subjectivity on the eve of the Revolution and let her connect them to a more coherent narrative of symbolically inflected events after 1789 . Hunt adumbrated a generalizable theory about the investment of charisma in male authorities, which she instantiated in divergences between the French and American Revolutions (Hunt, 1993, pp. 71-73, 199).

By analogous recourse to Marxist theory, C.B. MacPherson set in motion a fecund interrogation of well-known texts from seventeenth- and eighteenthcentury England. By retracing command over mortal labor as a newly-minted commodity in capitalist society, MacPherson recast Hobbes, the Levellers, 
Harrington, and Locke as elaborators of 'possessive individualism'. Most controversially, MacPherson hypothesized that the Levelers in the English Revolution could not entertain the notion of freedom except as 'a function of proprietorship' (Davis, 1968; Howell and Brewster, 1970). That is why he thought Levellers included small entrepreneurs, not wage laborers, as legitimate voters in the commonwealth. Political spokespersons equated 'ownership' or uncoerced use of one's labor power with disposal over one's spiritual person, so they ensconced it as a requisite for decision making in democratic political deliberations (MacPherson, 1962, pp. 137-159). From this startling deciphering, MacPherson reached the general verdict that the operative premises of capitalism frustrate any viable theory of free assent and therefore of legitimate obligation in liberal democracy (p. 275). When a thicker perspectival reading supports a cogent rearticulation of Marx's paradigm like this, we apprehend the touchstone of ramifying power. ${ }^{7}$

Among other worthy criteria, these three benchmarks of systemic coherence, contextual breadth, and ramifying power show how the robustness of humanistic interpretations can be judged in orderly fashion (Chartier, 1985; Griswold, 1987a; Grubich-Simitis, 1993; Risjord, 2000; Skinner, 2002, pp. 35-39; 55-56). My enterprise all along has been to vindicate humanistic interpretation as fulfilling norms of science more genuinely than formalized counting (Biernacki, 2012b, pp. 3-4, 145-146, 153).

In part because we lack a scale by which to rank the importance of separate standards as well as a metric of interpretive success, investigators are unlikely to converge on one best interpretation for long. This seems to hold in most branches of sociology. Investigators across many fields of the discipline debate whether the ability to closely fit profiles of a data set, or the diversity in the range of phenomena a theory explains, or theoretical depth and parsimony, or the ability to guide action for our collective future, or other concerns should be installed as paramount. In this light, humanistic interpreters scarcely exhibit distinctive resistance to empirical critique and consensus formation (Meehl, 1978; Wright et al, 1992, pp. 129-177; Wright, 2005). Endless technical innovation for reconstruing quantitative data from the 1966 Coleman Report, for example, reminds us that social scientific conclusions attain credibility rather than 'closure' (Borman and Dowling, 2010).

\section{How Thick Evidence Disciplines Research}

Humanistic interpretation is nonetheless distinctive for its reliance on density, intricacy, and variegation in what it takes for evidence. Several practical

\footnotetext{
${ }^{7}$ For an interpretation of texts that demonstrates the ramifying power of Foucault's paradigm of individualization, see Kharkhordin (1999).
} 
considerations vindicate this complexity as more rigorous than formalizing approaches. First, a cultural investigator can be likened to a crime detective who uses 'abduction'. The detective reasons backwards from detailed traces at the scenes of events toward guesses about the cultural and material devices the human perpetrators in all likelihood used to solve challenges in the moment of action (Walton, 2004, pp. 209-214). We erase the clues at the scene of the happening if we formalize by counting. We need to preserve the clues in all their oddity to detect how people came to deposit informative wrinkles and to extrapolate what the cues may tell us about human conduct. The formalizing method does not get us around this scholarly game of speculation and corroboration, because sociologists starting from counts are no more able to use induction or deduction to warrant a revelation (Tavory and Timmermans, 2014, pp. 37-38).

Second, since there are no sure-fire axioms for grasping what is 'going on' overall in documents or in patterns of action, we must preserve the vividness and articulation of the originals to generate fresh proposals about their 'rules of becoming' as constellations (Holly, 1985, p. 181). Uniquely rich sentences or architectural detail are necessary ingredients for what interpreters call synoptic insight, moment of fixation, point of impression, 'ebriety of the moment' - any of the 'aha's' by which researchers move in a flash from a part, taken as a miniature or metonymic point of entry, toward a new appreciation of the symbolic workings of the whole (Kermode, 1979, p. 136; Biernacki, 1995, p. 51; Ankersmit, 2005, pp. 126-128). Humanistic method preserves arcane detail because none of it in a text is automatically privileged, which is to say, almost any of it can become a cornerstone thanks to shifting the frame of reference (Biernacki, 2012b, p. 136). To maximize the potential of 'surprise' for theorizing (Swedberg, 2014, p. 238), we must preserve the minutia as pivots of interpretation and therefore as source points for competing guesses. A need for concreteness sustains unabated pressure, whereas the criterion of 'closure' seems to lubricate orthodoxy rather than science.

Finally, from the humanistic perspective greater complexity in the phenomena from which we 'abduct' sets up a more demanding threshold for tentatively confirming a hypothesis. Let us suppose that Lee and Martin were correct that a verbal hypothesis about intellectual affiliation or difference could be assessed by frequency of word pairs. Nonetheless, the conditions for affirming an interpretation would be unreasonably lowered by simplifying the data. The investigator need confirm only that one word heap has 'more of X' and another heap 'less'. As Paul Meehl diagnosed, testing in the mode of significant correlations or preponderances is far less demanding than is testing whether an interpretation coherently fits a complex sequence or qualitative constellation (Meehl, 1967, Meehl, 1978, pp. 817, 825). 
To illustrate the exactitude required for explaining qualitative patterns, consider again the testing that the cultural investigator Amir Alexander satisfied to evince how a materialistic schema of action organized mathematical problem-solving in early modern Europe (Biernacki, 2014b, pp. 182-183). When an interpreter hypothesizes that agents rely on a historically specific template for perception, expression, or action, they offer a bold conjecture vulnerable to disqualification. Alexander risked a hypothesis by trying it out on Thomas Hariot's procedures of mathematical 'proof', this mathematician's analysis of continua, quirks in his mapmaking, and his treatment of Zeno's paradox. Each was potentially disconfirming, because Alexander chose unanticipated situations in which it was easy to specify how Hariot might not have treated mathematical objects as irreducibly physical objects (Alexander, 2002, pp. 132, 154, 169). Exploring the minute consistency in an influential mathematician's practice can confirm a shared habitus or outlook with more stringency than starting with a sample from which an investigator classifies practice only in the aggregate (Alexander, pp. 212-213).

It is by this principle that Pierre Bourdieu in Distinction inadvertently confirms how quantification relaxes testing (Biernacki, 2012a, pp. 52-54). As we know, Bourdieu compares the frequency with which persons agree that a sunset over the sea is suitable material for a beautiful photograph (Bourdieu, 2007, p. 38). Persons with low occupational and educational rankings are more likely to affirm this subject matter as promising than are persons with high occupational and educational rankings. Supposedly this result confirms that persons with more education deploy a distinctive habitus by which they distance themselves from the trite and commonplace. The numbers confirm a differential, to be sure, but they also permit us to foreground what we like and to push into the background a convergence: the majority of respondents in every occupational and educational category approved the sunset as appropriate for a beautiful photograph. Only by adopting Bourdieu's frame of reference do we interpret this quantitatively preponderant result as subordinate and by contrast interpret the aggregate differential between classes as confirming the hypothesis that a class-based habitus generates individuals' 'taste' in photography. By formalizing people's esthetic appreciation into countable agree/disagree results, Bourdieu made it facile to confirm his hypothesis. His conjectures about class habitus would have been vulnerable to genuine trials had he descended to the level of individuals to discover on their own terms how they experience art in situ (Lahire, 2004, p. 164; Bennett, 2008, pp. 62, 70).

As I once hoped to evince via a comparative dissection of archival documents about nineteenth-century factories (Biernacki, 1995), preserving the minutia of sources can uphold more rigorous searching and tests for patterning. This selfdisciplining spirit lets me welcome Lee and Martin's acute formalizing even as I criticize it. Lee, Martin and I break with the middling kind of sociology that interpretive or descriptive coding represents. We agree the center cannot hold. 


\section{Postscript: The Vanishing Texts}

It is useful to correct a misstatement in Lee and Martin's article (LM, p. 2). None of the sociologists whose method I scrutinized in Reinventing Evidence via their inputs and outputs proved able to retrieve a research record of any kind, although several graciously tried and provided advice for approximate replication (Biernacki, 2012b, pp. 22, 127). Quantitatively-inspired text coding or counting tries to supplant real texts with secondary ciphers to the point of making the originals drop from sight. Only with Peter Bearman's generous tips on how to search, not from a reference in his published research, could I hunt down his Nazi autobiography among hundreds in the Hoover Institution Archives. We may imitate the sampling protocols and inspect texts cited as examples, but we will never learn comprehensively which sources were netted by John Evans and Wendy Griswold (Biernacki, 2012b, p. 63). Nor will we view the codes they assigned to these sources, apart from a few published clues. To me it is emblematic of the degradation of texts that Lee and Martin fail to reference any of the Englishlanguage editions that they formalized, rendering Horkheimer's and Adorno's work uncheckable. Perhaps this reflects the grand circle: quantified passages are never cited for quotes or paraphrases to warrant the ordinary readings of them that Lee and Martin say warranted the quantifying in turn (LM, p. 19, 29). No one perfectly satisfies the humanistic norm of footnoting accurately what came from exactly where, and I have surely deviated from it here. Yet the practices by which one hoists formalized 'data' as evidence almost naturally demean transparency.

\section{About the Author}

Richard Biernacki is author of Reinventing Evidence in Social Inquiry (New York: Palgrave Macmillan, 2012). He has also published comparative historical studies of the commercialization of human activity, including The Fabrication of Labor: Germany and Britain, 1640-1914 (Berkeley: University of California Press, 1995).

\section{References}

Abrams, M.H. (1989) Doing Things with Texts. Essays in Criticism and Critical Theory. New York: W.W. Norton \& Co.

Alexander, A. (2002) Geometrical Landscapes: The Voyages of Discovery and the Transformation of Mathematical Practice. Stanford, CA: Stanford University Press.

Ankersmit, F.R. (2001) Historical Representation. Stanford, CA: Stanford University Press. 
Ankersmit, F.R. (2005) Sublime Historical Experience. Stanford, CA: Stanford University Press.

Ascher, Ivan. (2010) Max weber and the 'spirit' of 'the protestant ethic'. Journal of Classical Sociology 10(2): 99-108.

Beardsley, M.C. (1958) Aesthetics. Problems in the Philosophy of Criticism. New York: Harcourt, Brace and Company.

Bearman, P. and Stovel, K. (2000) Becoming a nazi: A model for narrative networks. Poetics 27(2-3): 69-90.

Belaval, Y. (1966) Philosophers and Their Language. Athens, OH: Ohio University Press.

Belluck, P. (2015) Memories weaken without reinforcement, study finds. The New York Times 17 March: A8.

Bennett, T. (2008) Habitus Clivé. Aesthetics and politics in the work of Pierre Bourdieu. In: P. Goldstein and J. Machor (eds.) New Directions in American Reception Study. Oxford: Oxford University Press, pp. 57-86.

Berribi-Hoffman, I. (2013) Penser le changement au-delà des acteurs et des institutions. La Cultural Sociology aux Ètats-Unis (1990-2012). Socio 1: 173-195.

Biernacki, R. (1995) The Fabrication of Labor: Germany and Britain, 1640-1914. Berkeley, CA: University of California Press.

Biernacki, R. (2009) The banality of misrepresentation. In: I. Reed and J. Alexander (eds.) Meaning and Method. The Cultural Approach to Sociology. Boulder, CO: Paradigm Publishers, pp. 253-262.

Biernacki, R. (2012a) Rationalizing processes inside cultural sociology. In: J. Alexander, R. Jacobs and P. Smith (eds.) The Oxford Handbook of Cultural Sociology. Oxford: Oxford University Press, pp. 46-69.

Biernacki, R. (2012b) Reinventing Evidence in Social Inquiry: Decoding Facts and Variables. New York: Palgrave Macmillan.

Biernacki, R. (2014a) Cultural coherence in early modern England: The invention of contract. American Journal of Cultural Sociology 2(3): 277-299.

Biernacki, R. (2014b) Humanist interpretation versus coding text samples. Qualitative Sociology 37(2): 173-188.

Borman, G. and Dowling, M. (2010) Schools and inequality: A multilevel analysis of coleman's equality of educational opportunity data. Teachers College Record 112(5): 1201-1246.

Borges, J.L. (1962) Ficciones. New York: Grove Press.

Bourdieu, P. (1985) The market of symbolic goods. Poetics 14(1-2): 13-44.

Bourdieu, P. (2007) Distinction. A Social Critique of the Judgement of Taste. Cambridge, MA: Harvard University Press.

Bremer, M. (2001) Vernunft: Verstand. In: J. Karlfried, K. Gründer and G. Gabriel (eds.) Historisches Wörterbuch der Philosophie. Volume 11. Basel, Swittzerland: Schwabe \& Co, pp. $748-863$.

Burke, K. (1968) Counter-Statement. Berkeley, CA: University of California Press.

Busa, R. (1949) La terminologia tomistica dell'interiorità: saggi di metodo per un'interpretazione della metafisica della presenza. Milan, Italy: Fratelli Bocca.

Busa, R. (1980) The annals of humanities computing: The index thomasticus. Computers and the Humanities 14(2): 83-90.

Büttgen, P. (2004) Beruf. In: B. Cassin (ed.) Vocabulaire européen des philosophies. Dictionnaire des intraduisibles. Paris, France: Éditions de Seuil, pp. 186-190. 
Chartier, R. (1985) Text, symbols, and frenchness. Journal of Modern History 57(4): 682-695.

Conze, W. (1972) Beruf. In: O. Brunner, W. Conze and R. Koselleck (eds.) Geschictliche Grundbegriffe. Volume One. Stuttgart, Germany: Ernst Klett, pp. 490-507.

Corral, W. and Patai, D. (eds.) (2005) Theory's Empire: An Anthology of Dissent. New York: Columbia University Press.

Craig, H. (2004) Stylistic analysis and authorship studies. In: S. Schreibman, R. Siemens and J. Unsworth (eds.) A Companion to Digital Humanities. Oxford: Blackwell, pp. 273-288.

Darnton, R. (1984) The Great Cat Massacre and Other Episodes in French Cultural History. New York: Basic Books.

Davis, J.C. (1968) The levellers and democracy. Past \& Present 40: 174-180.

de Man, P. (1979) Allegories of Reading. New Haven, CT: Yale University Press.

DiMaggio, P., Nag, M. and Blei, D. (2013) Exploiting affinities between topic modeling and the sociological perspective on culture: Application to newspaper coverage of U.S. government arts funding. Poetics 41(6): 570-606.

Dubost, J.-P. (2004) Combinatoire et conceptualisation. Une 'métaphysique des particules' en allemand. In: B. Cassin (ed.) Vocabulaire européen des philosophies. Dictionnaire des intraduisibles. Paris, France: Éditions de Seuil, pp. 229-240.

Duhem, P.M.M. (1962) The Aim and Structure of Physical Theory. Princeton, NJ: Princeton University Press.

Eco, U. (1994) The Limits of Interpretation. Bloomington, IN: Indiana University Press.

Empson, W. (1951) The Structure of Complex Words. London: Chatto \& Windus.

Evans, J.E. (2002) Playing God? Human Genetic Engineering and the Rationalization of Public Bioethical Debate. Chicago, IL: University of Chicago Press.

Feldman, K. (2006) Binding Words. Conscience and Rhetoric in Hobbes, Hegel, and Heidegger. Evanston, IL: Northwestern University Press.

Fischer, H.K. (1982) [1907]) Kritische Beiträge zu Professor Max Webers Abhandlung. In: J. Winckelmann (ed.) Die Protestantische Ethik II. Kritiken und Antikritiken. Gütersloh, Germany: Gerd Mohn, pp. 11-26.

Frey, C. (2008) $\kappa \lambda \tilde{\eta} \sigma \varsigma /$ Beruf: Luther, Weber, Agamben. New German Critique 35(3): $35-56$.

Franzosi, R. (2004) From Words to Numbers. Cambridge, UK: Cambridge University Press.

Friedman, L.J. (2013) The Lives of Erich Fromm. Love's Prophet. New York: Columbia University Press.

Fromm, E. (1955) The human implications of instinctivistic 'radicalism'. Dissent 2(4): 342-349.

Fromm, E. (1956) A counter-rebuttal. Dissent 3(1): 81-83.

Galay, J.-L. (1977) Philosophie et invention textuelle. Essai sur la poétique d'un texte kantien. Paris, France: Éditions Klincksieck.

Garfinkel, A. (1967) Studies in Ethnomethodology. Englewood Cliffs, N.J.: Routledge \& K. Paul.

Geeraerts, D. (2010) Theories of Lexical Semantics. Oxford: Oxford University Press.

Genette, G. (1982) Palimpsestes. La littérature au second degré. Paris, France: Éditions du seuil. 
Gentner, D. and Jeziorski, M. (1993) The shift from metaphor to analogy in western science. In: A. Ortony (ed.) Metaphor and Thought. 2nd edn. Cambridge, UK: Cambridge University Press, pp. 447-480.

Gigerenzer, G. (2007) Gut Feelings. The Intelligence of the Unconscious. New York: Viking Penguin.

Gladdis, J.S. (2002) The Landscape of History. How Historians Map the Past. Oxford: Oxford University Press.

Goffman, E. (1974) Frame Analysis. An Essay on the Organization of Experience. New York: Harper \& Row.

Goodman, N. (1976) Languages of Art: An Approach to a Theory of Symbols. Indianapolis, IN: Hackett.

Goodman, Nelson (1978) Ways of Worldmaking. Indianapolis, IN: Hackett.

Goodman, N. and Elgin, C. (1988) Reconceptions in Philosophy and Other Arts and Sciences. Indianapolis, IN: Hackett.

Grice, H.P. (1957) Meaning. The Philosophical Review 66(3): 377-388.

Griswold, W. (1987a) A methodological framework for the sociology of culture. Sociological Methodology 17: 1-35.

Griswold, W. (1987b) The fabrication of meaning: Literary interpretation in the United States, Great Britain, and the West Indies. American Journal of Sociology 92(5): 1077-1117.

Grubich-Simitis, I. (1993) Back to Freud's Texts. Making Silent Documents Speak. New Haven, CT: Yale University Press.

Guignon, C. (2002) Truth in interpretation: A hermeneutic approach. In: M. Krausz (ed.) Is There a Single Right Interpretation? University Park, PA: Pennsylvania State University Press, pp. 264-284.

Habermas, J. (1987a) The Theory of Communicative Action. Volume 2. Boston, MA: Beacon Press.

Habermas, J. (1987b) The Philosophical Discourse of Modernity. Cambridge, MA: The MIT Press.

Hall, G. (2012) Has critical theory run out of time for data-driven scholarship? In: M. Gold (ed.) Debates in the Digital Humanities. Minneapolis, MN: University of Minnesota Press, pp. 127-136.

Halliday, M.A.K. (2002) Linguistic Studies of Text and Discourse. London: Continuum.

Hanks, W.F. (1996) Language and Communicative Practices. Boulder, CO: Westview.

Hawthorn, J. (1994) A Glossary of Contemporary Literary Theory. 2nd edn. London: Edward Arnold.

Heintz, B. (2007) Zahlen, Wissen, Objektivität: Wissenschaftssoziologische Perspecktiven. In: A. Mennicken and H. Hendrik Vollmer (eds.) Zablenwerk: Kalkulation, Organisation und Gesellschaft. Wiesbaden, Germany: VS Verlag für Sozialwissenschaften, pp. 65-85.

Herman, D. (2002) Story Logic. Problems and Possibilities of Narrative. Lincoln, NE: University of Nebraska Press.

Hirsch, E.D. (1967) Validity in Interpretation. New Haven, CT: Yale University Press.

Holly, M.A. (1985) Panofsky and the Foundations of Art History. Ithaca, NY: Cornell University Press.

Holub, R.C. (1993) The enlightenment of dialectic: Jürgen Habermas's critique of the frankfurt school. In: W.D. Wilson and R. Holub (eds.) Impure Reason. Dialectic of Enlightenment in Germany. Detroit, MI: Wayne State University Press, pp. 34-47. 
Honneth, A. (1991) The Critique of Power. Cambridge, MA: MIT Press.

Honneth, A. (2000) The possibility of a disclosing critique of society: The dialectic of enlightenment in light of current debates in social criticism. Constellations 7(1): 116-127.

Hobbs, J.R., Stickel, M., Appelt, D. and Martin, P. (1993) Interpretation as abduction. Artificial Intelligence 63: 69-142.

Horkheimer, M. and Adorno, T. (1944) Philosophische Fragmente. New York: Institute of Social Research.

Horkheimer, M. and Adorno, T. (2002) Dialectic of Enlightenment. [Dialektik der Aufklärung]. Stanford, CA: Stanford University Press.

Howell, Jr. R. and Brewster, D.E. (1970) Reconsidering the levellers: The evidence of The Moderate. Past \& Present 46: 68-96.

Hunt, L. (1993) The Family Romance of the French Revolution. Berkeley, CA: University of California Press.

Jameson, F. (1981) The Political Unconscious. Narrative as a Socially Symbolic Act. Ithaca, NY: Cornell University Press.

Jay, M. (1990) Fieldwork and theorizing in intellectual history. A reply to Fritz Ringer. Theory and Society 19(3): 311-321.

Joas, H. (1992) An underestimated alternative: America and the limits of 'critical theory'. Symbolic Interaction 15(3): 261-275.

Juola, P. (2006) Authorship attribution. Foundations and Trends in Information Retrieval 1(3): 233-334.

Kermode, F. (1975) The Classic. Literary Images of Permanence and Change. New York: The Viking Press.

Kermode, F. (1979) The Genesis of Secrecy. On the Interpretation of Narrative. Cambridge, MA: Harvard University Press.

Kharkhordin, O. (1999) The Collective and the Individual in Russia. A Study of Practices. Berkeley, CA: University of California Press.

Kilgarriff, A. (1997) 'I don't believe in word senses'. Computers and the Humanities 31(2): 91-113.

Kilgarriff, A. (2003) What computers can and cannot do for lexicography or us precision, them recall. Brighton, UK: Brighton University Information Technology Research Institute. Tech. Rep. ITRI-03-16.

Kjellmer, G. (1993) Multiple meaning and interpretation: The case of 'sanction'. Zeitschrift für Anglistik and Amerikanistik 41(2): 115-123.

Kuhn, T. (1970) The Structure of Scientific Revolutions. Chicago, IL: University of Chicago Press.

Kuhn, T. (1977) The Essential Tension. Chicago, IL: University of Chicago Press.

LaCapra, D. (1983) Rethinking Intellectual History: Texts, Context, Language. Ithaca, NY: Cornell University Press.

Lakatos, I. (1970) Falsification and the methodology of scientific research programmes. In: I. Lakatos and A. Musgrave (eds.) Criticism and the Growth of Knowledge. Cambridge, UK: Cambridge University Press, pp. 91-196.

Lamarque, P. (2002) Appreciation and literary interpretation. In: M. Krausz (ed.) Is There a Single Right Interpretation? University Park, PA: Pennsylvania State University Press, pp. 285-306. 
Lahire, B. (2004) La culture des individus. Dissonances culturelles et distinction de soi. Paris, France: Découverte.

Latour, B. (1987) Science in Action: How to Follow Scientists and Engineers Through Society. Cambridge, MA: Harvard University Press.

Lee, M. and Martin, J.L. (2015) Coding, counting, and cultural cartography. American Journal of Cultural Sociology 3(1): 1-33.

Library Journal (1972) 97 (August): 2645.

Lipton, P. (2004) Inference to the Best Explanation. 2nd edn. London: Routledge.

Lucy, J. (1997) The linguistics of color. In: C. Hardin and L. Maffi (eds.) Color Categories in Thought and Language. Cambridge, UK: Cambridge University Press, pp. 320-346.

MacIntyre, A. (1971) Against the Self-Images of the Age. New York: Schocken.

McKean, E. (2009) Redefining definition. New York Times Magazine 20 December, p. MM16.

McLaughlin, N. (1999) Origin myths in the social sciences: Fromm, the Frankfurt school and the emergence of critical theory. Canadian Journal of Sociology 24(1): 109-139.

Marcuse, H. (1955) The social implications of freudian 'revisionism'. Dissent 2(3): 221-240.

Marcuse, H. (1956) A reply to Erich Fromm. Dissent 3(1): 79-81.

Marcuse, H. (1966) Eros and Civilization. A Philosophical Inquiry into Freud. Boston, MA: Beacon Press.

Macleod, C., Grishman, R. and Meyers, A. (2000) Dictionaries and balanced corpora: The interdependence of resources. New York: New York University, Department of Computer Science, http://nlp.cs.nyu.edu/publication/papers/balanced.ps.

MacPherson, C.B. (1962) The Political Theory of Possessive Individualism. Oxford: Oxford University Press.

McCarty, W. (2004) Modeling: A study in words and meanings. In: S. Schreibman, R. Siemens and J. Unsworth (eds.) A Companion to Digital Humanities. Oxford: Blackwell, pp. 254-270.

Marschall, A.H. (1985) Review of theory and history of folklore. MLN Comparative Literature 100(5): 1123-1126.

Meehl, P. (1967) Theory-testing in psychology and physics: A methodological paradox. Philosophy of Science 34(2): 103-115.

Meehl, P. (1978) Theoretical risks and tabular asterisks: Sir Karl, Sir Ronald, and the slow progress of soft psychology. Journal of Consulting and Clinical Psychology 46(4): 806-834.

Monmonier, M. (1996) How to Lie with Maps. 2nd edn. Chicago, IL: University of Chicago Press.

Murphy, G. and Medin, D. (1999) The role of theories in conceptual coherence. In: E. Margolis and S. Laurence (eds.) Concepts. Core Readings. Cambridge, MA: The MIT Press, pp. 425-458.

Noerr, G.S. (2002) Editor's afterward. In: M. Max Horkheimer and T. Theodor Adorno (eds.) Dialectic of Enlightenment. Philosophical Fragments. Stanford, CA: Stanford University Press, pp. 218-247.

Nordh, G. and Zanuttini, B. (2008) What makes propositional abduction tractable. Artificial Intelligence 172(10): 1245-1284.

Pakkala-Weckström, M. (2008) 'No botmeles bihestes'. Various ways of making binding promises in middle english. In: A. Jucker and I. Taavitsainen (eds.) Speech Acts in the History of English. Amsterdam, the Netherlands: John Benjamins, pp. 133-162.

Pettersson, T. (2002) The literary work as a pliable entity: Combining realism and pluralism. In: M. Krausz (ed.) Is There a Single Right Interpretation? University Park, PA: Pennsylvania State University Press, pp. 211-230. 
Pocock, J.G.A. (1989) Politics, Language and Time. Chicago, IL: University of Chicago Press.

Propp, V. (1968) Morphology of the Folktale. Austin, TX: University of Texas Press.

Propp, V. (1983) Oedipus in light of folklore. In: E. Lowell and A. Dundes (eds.) Oedipus: A Folklore Casebook. New York: Garland, pp 76-121.

Punch (1953) Review of Lamming. 224: 24 June, pp. 753-754.

Quine, W.V. (1951) Main trends in recent philosophy: Two dogmas of empiricism. Philosophical Review 60(1): 20-43.

Ramsay, S. (2011) Reading Machines. Toward an Algorithmic Criticism. Urbana, IL: University of Illinois Press.

Reed, I.A. (2011) Interpretation and Social Knowledge. On the Use of Theory in the Human Sciences. Chicago, IL: University of Chicago Press.

Rescher, N. (2001) Philosophical Reasoning. A Study in the Methodology of Philosophizing. Oxford: Blackwell.

Ricoeur, P. (1981) Hermeneutics and the Human Sciences. Essays on Language, Action, and Interpretation. Cambridge, UK: Cambridge University Press.

Rieder, B. and Röhle, T. (2012) Digital methods: Five challenges. In: M. David and D.M. Berry (eds.) Understanding Digital Humanities. New York: Palgrave Macmillan, pp. 67-84.

Risjord, M. (2000) Woodcutters and Witchcraft. Rationality and Interpretive Change in the Social Sciences. Albany, NY: State University of New York Press.

Russell, P. (2008) The Riddle of Hume's 'Treatise'. Skepticism, Naturalism, and Irreligion. Cambridge, UK: Cambridge University Press.

Schindley, W.B.H. (2000) Work in the calling in Max Weber's Protestant ethic thesis. PhD thesis, University of North Texas, Denton, TX.

Schnädelbach, H. (1981) Zur Dialektik der historischen Vernunft. In: H.M. Baumgarten and H. Poser (eds.) Wandel des Vernunftbegriffs. Freiburg, Germany: Karl Alber, pp. 15-37.

Schulz, W.C. (1958) On categorizing qualitative data in content analysis. Public Opinion Quarterly 22(4): 503-515.

Sedgwick, E.K. (1985) Between Men. English Literature and Male Homosocial Desire. New York: Columbia University Press.

Silverstein, M. (1979) Language structure and linguistic ideology. In: P. Paul Clyne, W. Hanks and C. Hofbauer (eds.) The Elements: A Parasession on Linguistic Units and Levels. Chicago, IL: Chicago Linguistic Society, pp. 193-247.

Skinner, Q. (2002) Visions of Politics. Volume I: Regarding Method. Cambridge: Cambridge University Press.

Stewart, J. (2015) The linguistic forensics of the Fed's patience. The New York Times 13 March, B1.

Starobinski, J. (1980) Words upon Words: The Anagrams of Ferdinand de Saussure. New Haven, CT: Yale University Press.

Stubbs, M. (2007) Inferring meaning: text, technology and questions of induction. StudFuzz 209: 233-253.

Swedberg, R. (2014) The Art of Social Theory. Princeton, NJ: Princeton University Press.

Tanney, J. (2013) Rules, Reason, and Self-Knowledge. Cambridge, MA: Harvard University Press. 
Tarcov, N. (1988) Quentin Skinner's method and Machiavelli's Prince. In: J. Tully (ed.) Meaning and Context: Quentin Skinner and his Critics. Cambridge, UK: Cambridge University Press, pp. 194-203.

Tavory, I. and Timmermans, S. (2014) Abductive Analysis. Theorizing Qualitative Research. Chicago, IL: University of Chicago Press.

Taylor, C. (1979) Interpretation and the sciences of man. In: P. Rabinow and M. Sullivan (eds.) Interpretive Social Science. A Reader. Berkeley, CA: University of California Press, pp. 25-71.

Teubert, W. (2005) My version of corpus linguistics. International Journal of Corpus Linguistics 10(1): 1-13.

Times British Colonies Review (1953) Versatile writers from the West Indies, Summer: 45.

Travis, C. (2000) Unshadowed Thought. Representation in Thought and Language. Cambridge, MA: Harvard University Press.

Turner, T. (1969) Oedipus: Time and structure in narrative form. Forms of Symbolic Action: The Proceedings of the 1969 Annual Spring Meeting of the American Ethnological Society. Seattle, Washington DC: University of Washington Press, pp. 26-68.

Vanderveken, D. (1990) Meaning and Speech Acts. Volume One. Cambridge, UK: Cambridge University Press.

Van Peer, W. (1989) Quantitative studies of literature. A critique and an outlook. Computers and the Humanities 23(4-5): 301-307.

Velkley, R.L. (1989) Freedom and the End of Reason. Chicago: University of Chicago Press.

Vogel, S. (1996) Against Nature: The Concept of Nature in Critical Theory. Albany: State University of New York Press.

Waisman, S. (2005) Borges and Translation. The Irreverence of the Periphery. Lewisburg, PA: Bucknell University Press.

Walton, D. (2004) Abductive Reasoning. Tuscaloosa, AL: University of Alabama Press.

Weber, M. (1949) The Methodology of the Social Sciences. Glencoe, IL: The Free Press.

Weber, M. (1958) The Protestant Ethic and the Spirit of Capitalism. New York: Charles Scribner's Sons.

Weber, M. (1982a [1910]) Antikritisches zum 'Geist' des Kapitalismus. In: J. Winckelmann (ed.) Die Protestantische Ethik II. Kritiken und Antikritiken. Gütersloh, Germany: Gerd Mohn, pp. 149-187.

Weber, M. (1982b [1910]) Antikritisches Schlußwort zum 'Geist des Kapitalismus'. In: J. Winckelmann (ed.) Die Protestantische Ethik II. Kritiken und Antikritiken. Gütersloh, Germany: Gerd Mohn, pp. 283-345.

White, H. (1999) Figural Realism. Studies in the Mimesis Effect. Baltimore, MD: Johns Hopkins University Press.

Whorf, B. (1941) The relation of habitual thought and behavior to language. In: J.B. Carroll (ed.) Language, Thought, and Reality: Selected Writings of Benjamin Lee Whorf. Cambridge, MA: The MIT Press, pp. 134-159.

Wittenberg, D. (2001) Philosophy, Revision, Critique. Stanford, CA: Stanford University Press.

Wittgenstein, L. (1958) Philosophical Investigations. Oxford: Blackwell.

Wright, E.O., Levine, A. and Sober, E. (1992) Reconstructing Marxism. Essays on the Explanation and the Theory of History. London: Verso. 
Wright, E.O. (2005) Approaches to Class Analysis. Cambridge, UK: Cambridge University Press.

Zammito, J. (2004) A Nice Derangement of Epistemes. Chicago, IL: University of Chicago Press.

Supplementary information accompanies this article on the American Journal of Cultural Sociology website (www.palgrave-journals.com/ajcs). 